\title{
Can 3-D models explain the observed fractions of fossil and non-fossil carbon in and near Mexico City?
}

\author{
A. Hodzic ${ }^{1}$, J. L. Jimenez ${ }^{2}$, A. S. H. Prévôt ${ }^{3}$, S. Szidat ${ }^{4}$, J. D. Fast ${ }^{5}$, and S. Madronich ${ }^{1}$ \\ ${ }^{1}$ NCAR Earth System Laboratory, Boulder, CO, USA \\ ${ }^{2}$ Dept. of Chemistry and Biochemistry, and CIRES, University of Colorado, Boulder, CO, USA \\ ${ }^{3}$ Laboratory of Atmospheric Chemistry, Paul Scherrer Institut, Switzerland \\ ${ }^{4}$ Dept. of Chemistry and Biochemistry, and Oeschger Centre for Climate Change Research, \\ University of Bern, Switzerland \\ ${ }^{5}$ Pacifc Nortwest National Laboratory, Richland, WA, USA
}

Received: 4 May 2010 - Published in Atmos. Chem. Phys. Discuss.: 10 June 2010

Revised: 1 November 2010 - Accepted: 10 November 2010 - Published: 25 November 2010

\begin{abstract}
A 3-D chemistry-transport model has been applied to the Mexico City metropolitan area to investigate the origin of elevated levels of non-fossil (NF) carbonaceous aerosols observed in this highly urbanized region. High time resolution measurements of the fine aerosol concentration and composition, and 12 or $24 \mathrm{~h}$ integrated ${ }^{14} \mathrm{C}$ measurements of aerosol modern carbon have been performed in and near Mexico City during the March 2006 MILAGRO field experiment. The non-fossil carbon fraction $\left(f_{\mathrm{NF}}\right)$, which is lower than the measured modern fraction $\left(f_{\mathrm{M}}\right)$ due to the elevated ${ }^{14} \mathrm{C}$ in the atmosphere caused by nuclear bomb testing, is estimated from the measured $f_{\mathrm{M}}$ and the source-dependent information on modern carbon enrichment. The $f_{\mathrm{NF}}$ contained in $\mathrm{PM}_{1}$ total carbon analyzed by a US team $\left(f_{\mathrm{NF}}^{\mathrm{TC}}\right)$ ranged from 0.37 to 0.67 at the downtown location, and from 0.50 to 0.86 at the suburban site. Substantially lower values (i.e. 0.24-0.49) were found for $\mathrm{PM}_{10}$ filters downtown by an independent set of measurements (Swiss team), which are inconsistent with the modeled and known differences between the size ranges, suggesting higher than expected uncertainties in the measurement techniques of ${ }^{14} \mathrm{C}$. An increase in the non-fossil organic carbon $(\mathrm{OC})$ fraction $\left(f_{\mathrm{NF}}^{\mathrm{OC}}\right)$ by $0.10-0.15$ was observed for both sets of filters during periods with enhanced wildfire activity in comparison to periods when fires were suppressed by rain, which is consistent with the wildfire impacts estimated with other methods. Model results show that the relatively high fraction of nonfossil carbon found in Mexico City seems to arise from the combination in about equal proportions of regional biogenic SOA, biomass burning POA and SOA, as well as non-fossil
\end{abstract}

urban POA and SOA. Predicted spatial and temporal variations for $f_{\mathrm{NF}}^{\mathrm{OC}}$ are similar to those in the measurements between the urban vs. suburban sites, and high-fire vs. low-fire periods. The absolute modeled values of $f_{\mathrm{NF}}^{\mathrm{OC}}$ are consistent with the Swiss dataset but lower than the US dataset. Resolving the ${ }^{14} \mathrm{C}$ measurement discrepancies is necessary for further progress in model evaluation. The model simulations that included secondary organic aerosol (SOA) formation from semi-volatile and intermediate volatility (S/IVOC) vapors showed improved closure for the total OA mass compared to simulations which only included SOA from VOCs, providing a more realistic basis to evaluate the $f_{\mathrm{NF}}$ predictions. $f_{\mathrm{NF}}^{\mathrm{OC}}$ urban sources of modern carbon are important in reducing or removing the difference in $f_{\mathrm{NF}}$ between model and measurements, even though they are often neglected on the interpretation of ${ }^{14} \mathrm{C}$ datasets. An underprediction of biomass burning POA by the model during some mornings also explains a part of the model-measurement differences. The $f_{\mathrm{NF}}$ of urban POA and SOA precursors is an important parameter that needs to be better constrained by measurements. Performing faster $(\leq 3 \mathrm{~h}){ }^{14} \mathrm{C}$ measurements in future campaigns is critical to further progress in this area. To our knowledge this is the first time that radiocarbon measurements are used together with aerosol mass spectrometer (AMS) organic components to assess the performance of a regional model for organic aerosols.

Published by Copernicus Publications on behalf of the European Geosciences Union. 


\section{Introduction}

Organic aerosols (OA), composed of a complex mixture of primary (POA, emitted in the particle phase) and secondary (SOA, formed due to chemical reactions of organic vapors) compounds, account for a large fraction of the submicron particulate mass over continental regions $(20-80 \%$, Jimenez et al., 2009) and in the free troposphere (Murphy et al., 2006). Despite their ubiquity, the sources and formation processes of OA are still largely controversial with major consequences on our ability to predict and regulate OA levels and, therefore, their effects on climate and human health and their changes for future climate and emission scenarios. Of particular interest for pollution regulation is the ability to distinguish between the OA emitted from human activities, of which a major fraction involves fossil fuel burning (and that can be reduced using emission controls or non-combustion renewable energies) and $\mathrm{OA}$ generated by non-fossil sources such as biogenic SOA or biomass burning. We note that the fossil/non-fossil distinction does not map to controllable/uncontrollable sources: a fraction of biogenic SOA in polluted regions may be controllable (Carlton et al., 2010), and wildfire emissions can be partially managed through prescribed burning and other measures.

Over the past several decades radiocarbon analyses have provided insights into the relative contribution of fossil and modern sources of carbonaceous aerosols at different locations by measuring the ${ }^{14} \mathrm{C} /{ }^{12} \mathrm{C}$ ratio in ambient aerosol samples (Szidat, 2009a). Emissions from fossil fuel combustion do not contain ${ }^{14} \mathrm{C}$, as the geological age of the fuel is much larger than the half-life of ${ }^{14} \mathrm{C}$ of $\sim 5730$ years. Thus they can be separated from non-fossil carbon sources that have a similar amount of ${ }^{14} \mathrm{C}$ isotope as atmospheric $\mathrm{CO}_{2}$ when the carbon in the biomass was photosynthesized (e.g. Hildemann et al., 1994 and references therein). We define the non-fossil carbon fraction $\left(f_{\mathrm{NF}}\right)$ as the fraction of aerosol carbon which arises from sources for which the carbon has been recently fixed, such as forest fires, biogenic SOA, and food cooking. Similarly we can define the fossil carbon fraction $\left(f_{\mathrm{F}}\right)$ as the aerosol carbon arising from fossil sources, such as the combustion of fossil fuels or SOA formed from evaporation of fossil fuels such as gasoline. By definition $f_{\mathrm{NF}}+f_{\mathrm{F}}=1.0$. The traditionally reported modern carbon fraction $\left(f_{\mathrm{M}}\right.$, Stuiver and Polach, 1977) is higher than $f_{\mathrm{NF}}$ because $f_{\mathrm{M}}=1.0$ for atmospheric $\mathrm{CO}_{2}$ around 1950, but $f_{\mathrm{M}}$ of atmospheric $\mathrm{CO}_{2}$ increased greatly due to atomic bomb tests in 19551963 (Szidat et al., 2006; Levin et al., 2010). $f_{\mathrm{M}}$ of atmospheric $\mathrm{CO}_{2}$ reached almost 2.0 in the Northern Hemisphere in 1963, and has been slowly decreasing since. Biomass photosynthesized 30, 20, 10, and 0 years before the MILAGRO study in 2006 would have $f_{\mathrm{M}}$ of 1.37, 1.20, 1.12, and 1.06, respectively (Levin et al., 2010). Thus $f_{\mathrm{M}}+f_{\mathrm{F}}>1.0$, and it is important to keep in mind that always $f_{\mathrm{M}}>f_{\mathrm{NF}}$, with their ratio depending on the age of the biomass. We also will use EC, OC, or TC (for elemental, organic, or total carbon, respectively) as a superscript to indicate the carbon fraction whose NF fraction we are referring to (e.g. $f_{\mathrm{NF}}^{\mathrm{OC}}$ ).

Generally, ${ }^{14} \mathrm{C}$ measurements are performed on total carbon aerosols (TC) and the resulting modern fraction includes contributions from all carbonaceous aerosol components (i.e. both elemental carbon, EC, and organic carbon, OC). Recently, the quantification of ${ }^{14} \mathrm{C}$ in sub-fractions of $\mathrm{TC}$, such as EC and OC has been reported (Szidat et al., 2004). The availability of ${ }^{14} \mathrm{C}$ for these carbon fractions is very useful for source apportionment studies, as OC and EC are unlikely to contain the same fraction of fossil and nonfossil carbon due to the different relative source impacts. OC is emitted from primary sources but also formed as SOA and can partition between the gas and particle phases, and even volatilize back to the gas-phase upon heterogeneous oxidation. EC is exclusively generated by combustion of fossil fuels and biomass and is effectively chemically inert on atmospheric residence times of 1-2 weeks.

The results of aerosol radiocarbon studies have revealed the presence of large amounts of non-fossil carbon in both remote and urban environments of the Northern Hemisphere throughout the year. Rather surprisingly, substantial amounts of non-fossil carbon have been reported even in heavily urbanized areas (e.g. Los Angeles or Mexico City) where large quantities of fossil fuel are being burned. Measurements of $f_{\mathrm{TC}}^{\mathrm{NF}}$ reported in recent years are summarized in Fig. 1 and Table 1. One of the largest urban $f_{\mathrm{NF}}^{\mathrm{TC}}$ was reported in Albuquerque, New Mexico (0.76, Klinedinst and Currie, 1999). These levels are comparable to levels found in remote mountain environments $(0.62-0.87$ of non-fossil contribution in Puy-de-Dome, Gelencser et al., 2007; Legrand and Puxbaum, 2007) or in the Grand Canyon National Park $(>0.95)$ where the anthropogenic influence is expected to be small. Lower, but still substantial $f_{\mathrm{NF}}^{\mathrm{TC}}$ were found in the US urban agglomerations ranging from 0.29 to 0.56 (e.g. 0.29 0.38 in Los Angeles, Hildemann et al., 1994; or 0.49-0.56 in Phoenix, Bench et al., 2007), in Zurich (0.54-0.59, Szidat et al., 2006), in Beijing (0.33-0.48, Yang et al., 2005) and in Tokyo (0.30-0.40, Takahashi et al., 2007). Mexico City is no exception. Marley et al. (2009) have reported that modern carbon $\left(f_{\mathrm{M}}^{\mathrm{TC}}\right)$ ranged between $0.42-0.74$ within the city center, which corresponds to approximately $0.35-0.63 f_{\mathrm{NF}}^{\mathrm{TC}}$ as discussed below. Aiken et al. (2010) have quantified $f_{\mathrm{NF}}^{\mathrm{TC}}$ to range from 0.28 during low biomass burning periods to 0.41 during high biomass burning activity of March 2006 (MILAGRO field project). The presence of substantial levels of nonfossil TC in urban environments during low biomass burning periods poses the question of the influence of sources such as biogenic SOA, primary biological particles (PBAP), and urban sources of modern carbon (such as food cooking, biofuel use, tire wear etc.) on urban air quality. These sources are usually not well captured by current models, and radiocarbon data offers an additional constraint for OA modeling studies. 
A. Hodzic et al.: Can 3-D models explain the observed fractions of fossil and non-fossil carbon?

Table 1. ${ }^{14} \mathrm{C}$ apportionment studies showing the contribution of non-fossil carbon to Total Carbon (TC).

\begin{tabular}{|c|c|c|c|c|c|c|}
\hline Location & Site & Date & Size & $f_{\mathrm{NF}}(\%)$ & $\mathrm{TC}\left(\mu \mathrm{g} \mathrm{m}^{-3}\right)$ & Reference \\
\hline \multicolumn{7}{|c|}{ Sites located in the USA } \\
\hline \multirow[t]{2}{*}{ Los Angeles, CA } & URB & Jan-Dec 1982 & \multirow{2}{*}{$\mathrm{PM}_{2.1}$} & 29 & 9 & \multirow{2}{*}{ Hildemann et al. (1994) } \\
\hline & SUB & Jan-Dec 1982 & & 38 & 10 & \\
\hline Denver, CO & SUB & Aug 1996 & $\mathrm{PM}_{2.5}$ & 42 & 6.1 & Currie et al. (1994) \\
\hline \multirow{3}{*}{$\begin{array}{l}\text { Brighton, } \mathrm{CO} \\
\text { Albuquerque, NM }\end{array}$} & & Dec 1996-Jan 1997 & & 26 & 9.2 & Klinedinst and Currie (1999) \\
\hline & RUR & Dec 1996-Jan 1997 & & 26 & 5.9 & \\
\hline & URB & Dec 1985 & & 76 & 35 & \\
\hline Houston, TX & SUB & Aug 2002 & \multirow{3}{*}{$\mathrm{PM}_{2.5}$} & 48 & 4.1 & Lemire et al. (2002) \\
\hline Nashville, TN & SUB & Jun-Jul 1999 & & 64 & 5.0 & Lewis et al. (2004) \\
\hline Tampa, FL & SUB & May 2002 & & 70 & 3.1 & Lewis and Stiles (2006) \\
\hline N. Birmingham, AL & URB & Sep 2003-Jan 2004 & $\mathrm{PM}_{2.5}$ & 30 & 13 & \multirow{4}{*}{$\begin{array}{l}\text { Tanner et al. (2004) } \\
\text { Zheng et al. (2006) } \\
\text { Ke et al. (2007) }\end{array}$} \\
\hline Chattanooga, TN & URB & Mar-Apr 2003 & $\mathrm{PM}_{2.5}$ & 57 & 5.8 & \\
\hline Centreville, VA & RUR & Sep 2003-Jan 2004 & $\mathrm{PM}_{2.5}$ & 72 & 6.6 & \\
\hline Look Rock, TN & RUR & Summer 2001-2002 & $\mathrm{PM}_{10} / \mathrm{PM}_{2.5}$ & 74 & 5.5 & \\
\hline \multirow{2}{*}{ Phoenix, AZ } & \multirow{2}{*}{ URB } & Summer 2000-2005 & \multirow{4}{*}{$\mathrm{PM}_{2.5}$} & 56 & 2.3 & \multirow{4}{*}{$\begin{array}{l}\text { Bench et al. (2007) } \\
\text { Schichtel et al. (2008) }\end{array}$} \\
\hline & & Winter 2001-2006 & & 49 & 7.3 & \\
\hline \multirow{2}{*}{ Grand Canyon, AZ } & \multirow{2}{*}{ RUR } & Summer 2000-2005 & & 95 & 0.8 & \\
\hline & & Winter 2001-2006 & & 100 & 0.2 & \\
\hline Libby, MT & VAL & Nov 2003-Feb 2004 & $\mathrm{PM}_{2.5}$ & 82 & 20 & Ward et al. (2006) \\
\hline \multicolumn{7}{|c|}{ Sites located in Europe } \\
\hline Stockholm, S & URB & Nov 2005 & \multirow{2}{*}{ TSP } & 50 & 2.8 & \multirow{2}{*}{ Zencak et al. (2006) } \\
\hline Aspvreten, S & RUR & Nov 2005 & & 80 & 1.7 & \\
\hline \multirow{2}{*}{ Gothenburg, S } & \multirow{2}{*}{ URB-BCG } & Feb-Mar 2005 & $\mathrm{PM}_{10}$ & 56 & 3.0 & \multirow{2}{*}{ Szidat et al. (2009b) } \\
\hline & & Jun-Jul 2006 & $\mathrm{PM}_{2.5}$ & 53 & 2.7 & \\
\hline \multirow{2}{*}{ Aveiro, $\mathrm{P}$} & \multirow{2}{*}{ RUR } & Summer 2002-2003 & & 63 & 4.0 & \\
\hline & & Winter 2002-2004 & & 81 & 14.0 & \\
\hline \multirow{2}{*}{ K-Puszta, H } & & Summer 20020-2003 & & 82 & 5.0 & \\
\hline & KUK & Winter 2002-2004 & & 69 & 11.0 & \\
\hline & & May-Jun 2003 & $\mathrm{PM}_{2.5}$ & 78 & 1.6 & Gelencser et al. (2007) \\
\hline Sonnblick, A & $\mathrm{BCG}$ & Oct-Dec 2002 & & 65 & 0.21 & \\
\hline Puy de Dome FR & $\mathrm{BCG}$ & Jun 2003 & & 87 & 4.92 & \\
\hline ruy de Dome, & DCu & $\operatorname{Jan} 2002+\operatorname{Jan}+\operatorname{Dec} 2$ & & 62 & 0.86 & \\
\hline Zurich $\mathrm{CH}$ & URB_BCG & Aug-Sep 2002 & $\mathrm{PM}_{10}$ & 54 & 5.9 & Szidat et al (2004 2006) \\
\hline Zumch, CH & OND-DCU & Feb 2003 & $\mathrm{PM}_{10}$ & 59 & 19 & SZláal el al. $(2004,2000)$ \\
\hline Sedel, CH & RUR & Jan-Feb 2006 & $\mathrm{PM}_{10}$ & 63 & 26 & Szidat et al (2007) \\
\hline Roveredo, $\mathrm{CH}$ & RUR & Jan 2004 & $\mathrm{PM}_{10}$ & 83 & 16 & SzIuat et al. (200/) \\
\hline коveredo, СH & KUK & Nov-Dec 2004 & $\mathrm{PM}_{1}$ & 85 & 15 & \\
\hline & & & er locations & & & \\
\hline & URB & Jun + Aug 2002 & & 30 & 5.5 & \\
\hline Tokyo, J & URB & Apr + Oct 2002 & $\mathrm{PM}_{1.3}$ & 38 & 4.8 & Yamamoto et al. (2007) \\
\hline & URB & Dec 2002 + Feb 2003 & & 40 & 6.3 & \\
\hline & URB & Jun 2001 & & 48 & 27.8 & \\
\hline Be1jing, C & URB & Jan-Feb 2001 & $\mathrm{PM}_{2.5}$ & 33 & 50.9 & Yang et al. (2005) \\
\hline & URB & March 2006 & & 35 & 16.7 & Marley et al. (2009) \\
\hline Mexico City, MX & SUB & March 2006 & $\mathrm{PMI}_{1}$ & 63 & 20.5 & \\
\hline & URB & March 2006 & $\mathrm{PM}_{10}$ & 33 & 18.5 & \\
\hline
\end{tabular}




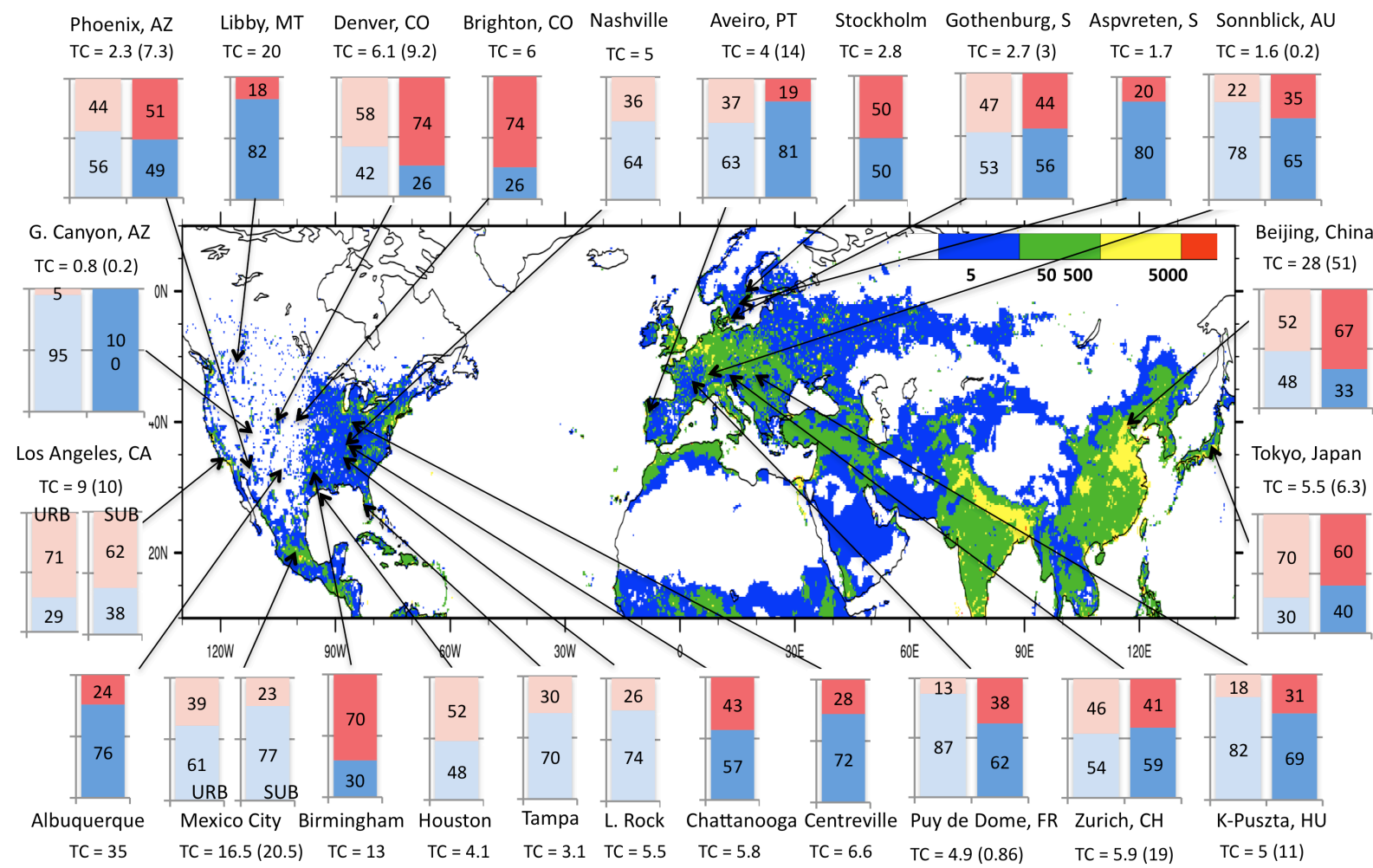

Fig. 1. Population density $\left(\mathrm{km}^{-2}\right)$ and the relative non-fossil (blue bars) and fossil (red bars) carbon reported in recent studies for the Northern Hemisphere. Summer (lighter colors) and winter (darker colors) are distinguished. When available, total carbon concentrations $\left(\mu \mathrm{gC} \mathrm{m}^{-3}\right)$ are also indicated for the summer and winter (in parenthesis) samples.

To estimate the relative contributions of fossil fuel combustion, biomass burning and biogenic SOA to OA concentrations, several studies (e.g. Gelencser et al., 2007; Szidat et al., 2009b) have combined radiocarbon measurements with analyses of specific organic tracers. This receptor-modeling approach is exclusively based on data and is sensitive to inaccuracies associated with measurements, missing or below detection limit observations, and to non-uniqueness or atmospheric degradation of tracers. The potential of using the radiocarbon measurements, in combination with other OA measurements, for 3-D model evaluation and source apportionment has not been explored to our knowledge. Such a combined approach may be useful to help interpret the apportionment of modern and fossil carbon between different POA and SOA sources, as the sources of carbonaceous aerosols cannot be directly determined from only ${ }^{14} \mathrm{C}$ measurements because of the contribution of multiple primary and secondary fossil and non-fossil sources.

In this study we combine the results of an air quality model with ${ }^{14} \mathrm{C}$ and AMS measurements acquired in Mexico City during the MILAGRO field study (March 2006). We have already shown in our previous work (Hodzic et al., 2009, 2010) that the model is able to reproduce the observed concentrations of primary and secondary OC within 30\% (a relatively small error given the current state of knowledge) dur- ing this campaign. However, there is insufficient evidence that this level of agreement is due to the right mixture of sources. The combined use of AMS and ${ }^{14} \mathrm{C}$ observations will help determine whether the model captures the concentrations and fractions of OC from modern and fossil carbon sources, or whether error compensation may be occurring among various OA sources. The goal of the paper is twofold: (i) to assess whether the current representation of OA in our model can explain the observed levels of non-fossil carbon in aerosols within Mexico City; and (ii) to use the model results to determine the relative contributions of urban sources, biomass burning, and biogenic emissions to the observed levels of carbon in the vicinity of Mexico City. As SOA formation is one of the major current uncertainties in OA modeling (e.g. Hallquist et al., 2009; de Gouw and Jimenez, 2009), we will examine the sensitivity of the results to the choice of the SOA parameterization. This type of analysis can help determine the strengths and weaknesses of current OA and SOA models. The terminology used for organic matter in this paper is summarized in Table 2 for reference. 
Table 2. Terminology used for the various fractions and sources of organic compounds.

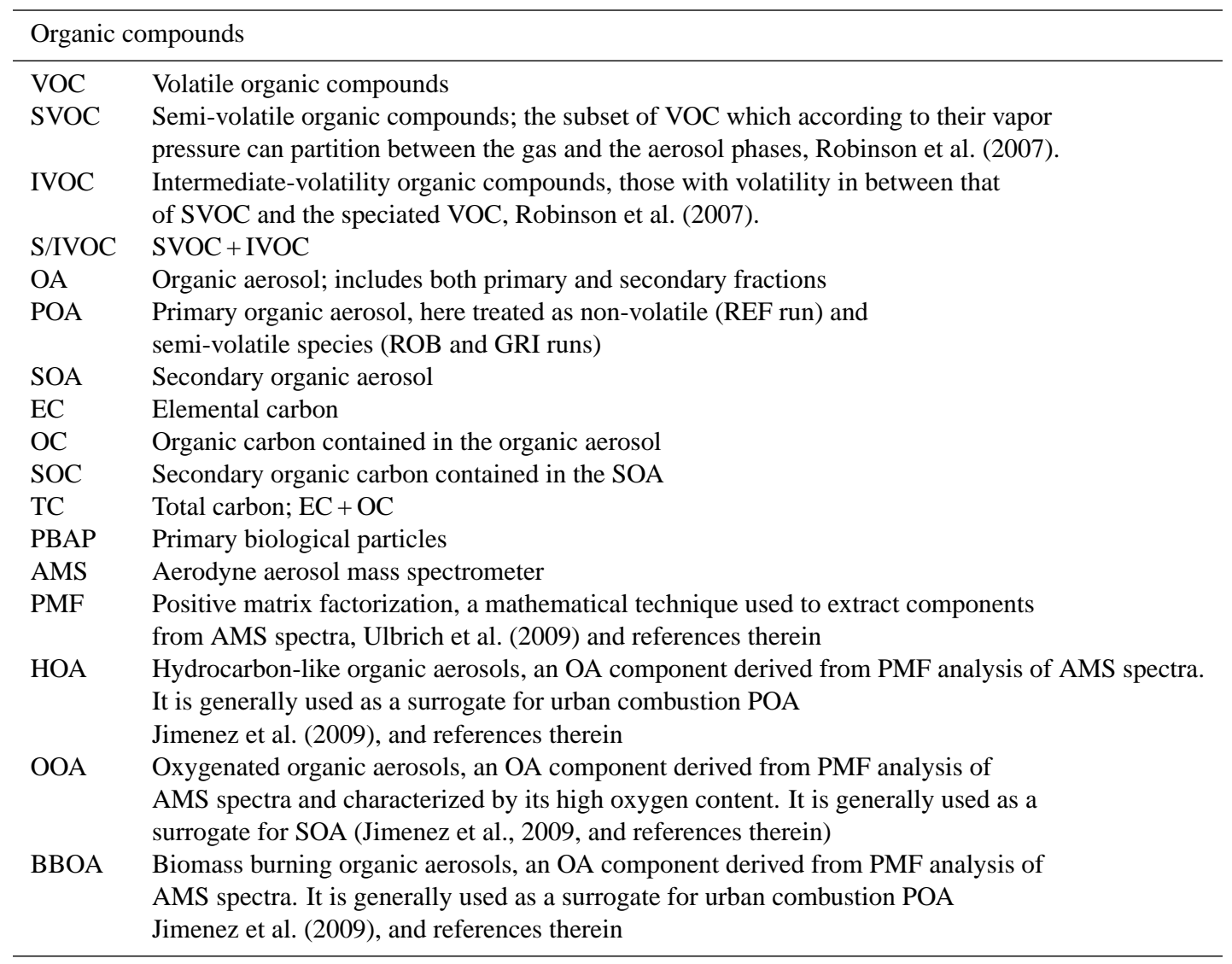

\section{Measurements}

Within the framework of the MILAGRO field experiment (Molina et al., 2010), aerosol samples were collected by two groups on quartz fiber filters during March 2006 at both urban (T0) and suburban (T1) locations in Mexico City and analyzed for ${ }^{14} \mathrm{C}$ content at two different laboratories. Available $f_{\mathrm{NF}}$ measurements for MILAGRO are summarized in Table 3 .

\subsection{Using $f_{\mathrm{M}}$ vs. $f_{\mathrm{NF}}$ for analysis and model-measurement comparison}

The analyses carried out in this paper could use either $f_{\mathrm{M}}$ or $f_{\mathrm{NF}}$. Each parameter has some advantages and disadvantages. The measurements report $f_{\mathrm{M}}$ directly, and to estimate $f_{\mathrm{NF}}$ one needs to make an assumption about the mixture of sources that are responsible for the measured modern carbon. On the other hand, $f_{\mathrm{NF}}$ is the physically meaningful quantity and its use is thus preferable. Also, the model calculates $f_{\mathrm{NF}}$ most directly, and additional assumptions about each source are needed to estimate $f_{\mathrm{M}}$. In addition, the use of $f_{\mathrm{M}}$ causes much confusion, as the large majority of the researchers in the OA field do not appear to be aware of the difference be- tween $f_{\mathrm{M}}$ and $f_{\mathrm{NF}}$ and thus they tend to interpret reported $f_{\mathrm{M}}$ values as if they were $f_{\mathrm{NF}}$, overestimating the importance of non-fossil sources. Considering the uncertainties in both measurements and model as well as the confusion introduced when $f_{\mathrm{M}}$ is used, we have chosen to only use $f_{\mathrm{NF}}$ in the remainder of this manuscript. The conclusions of this paper would not change if $f_{\mathrm{M}}$ was used instead.

\subsection{Estimates of $f_{\mathrm{NF}}^{\mathrm{OC}}$ in $\mathrm{PM}_{1}$ at the urban and suburban sites}

The first set of ${ }^{14} \mathrm{C}$ measurements (Marley et al., 2009, hereafter called "US dataset") was collected by scientists from the University of Arkansas on submicron filter samples over $12 \mathrm{~h}$ periods at the urban (T0) and suburban (T1) sites for both daytime (06:00-18:00 Local Time - LT) and nighttime (18:00-06:00 LT). Marley et al. (2009) reported $f_{\mathrm{M}}^{\mathrm{TC}}$ which includes modern carbon contained in both $\mathrm{EC}$ and $\mathrm{OC}$, and did not attempt to estimate $f_{\mathrm{NF}}^{\mathrm{TC}}$. For the purpose of this study, the fraction of modern carbon in OC was estimated by subtracting the modern carbon contribution from EC (see Table 3). To determine EC concentrations several datasets were available at $\mathrm{T} 0$ and $\mathrm{T} 1$ locations during MILAGRO as 
Table 3. Measured concentrations of TC and EC (BC) aerosols, and corresponding non-fossil fractions at urban and suburban sites during MILAGRO.

\begin{tabular}{|c|c|c|c|c|c|c|}
\hline Date & Period $^{1}$ & $\begin{array}{r}\mathrm{TC} \\
\mu \mathrm{gC} \mathrm{m}^{-3}\end{array}$ & $\begin{array}{c}\mathrm{EC}(\mathrm{BC})^{2} \\
\mu \mathrm{gC} \mathrm{m}^{-3}\end{array}$ & $f_{\mathrm{NF}}^{\mathrm{EC}}$ & $f_{\mathrm{NF}}^{\mathrm{TC}^{3}}$ & $f_{\mathrm{NF}}^{\mathrm{OC}}$ \\
\hline \multicolumn{7}{|c|}{ at the urban T0 site from Marley et al. (2008) } \\
\hline 11 Mar & DAY & 30.1 & 5.79 & & 0.55 & 0.67 \\
\hline $11 \mathrm{Mar}$ & NIGHT & 22.5 & 5.99 & & 0.60 & 0.80 \\
\hline 13 Mar & NIGHT & 15.5 & 4.25 & & 0.59 & 0.79 \\
\hline 17 Mar & NIGHT & 18.4 & 2.10 & & 0.55 & 0.61 \\
\hline 21 Mar & NIGHT & 10.0 & 4.36 & $0.05^{4}$ & 0.63 & 1.08 \\
\hline 23 Mar & DAY & 21.4 & 3.11 & & 0.46 & 0.52 \\
\hline 23 Mar & NIGHT & 9.7 & 2.45 & & 0.67 & 0.88 \\
\hline 27 Mar & DAY & 13.6 & 3.59 & & 0.37 & 0.49 \\
\hline 27 Mar & NIGHT & 8.8 & 1.85 & & 0.48 & 0.59 \\
\hline \multicolumn{7}{|c|}{ at the urban T0 site from Aiken et al. (2008b) } \\
\hline $21 \mathrm{Mar}$ & Daily & 15.8 & 2.29 & 0.13 & 0.49 & 0.55 \\
\hline $22 \mathrm{Mar}$ & Daily & 24.3 & 7.86 & 0.04 & 0.33 & 0.47 \\
\hline 26 Mar & Daily & 9.6 & 2.26 & 0.05 & 0.32 & 0.40 \\
\hline 29 Mar & Daily & 24.4 & 9.28 & 0.04 & 0.24 & 0.37 \\
\hline \multicolumn{7}{|c|}{ at the suburban T1 site from Marley et al. (2008) } \\
\hline 11 Mar & DAY & 17.1 & 1.74 & & 0.67 & 0.74 \\
\hline 11 Mar & NIGHT & 19.3 & 1.33 & & 0.63 & 0.68 \\
\hline 13 Mar & DAY & 96.9 & 1.89 & & 0.68 & 0.69 \\
\hline 13 Mar & NIGHT & 12.6 & 1.31 & & 0.78 & 0.86 \\
\hline 15 Mar & DAY & 16.4 & 1.60 & & 0.59 & 0.65 \\
\hline 15 Mar & NIGHT & 15.1 & 0.77 & & 0.64 & 0.67 \\
\hline 17 Mar & DAY & 14.4 & 1.46 & & 0.66 & 0.72 \\
\hline 17 Mar & NIGHT & 15.1 & 1.43 & & 0.68 & 0.74 \\
\hline 19 Mar & NIGHT & 10.1 & 0.83 & 0.05 & 0.78 & 0.84 \\
\hline 21 Mar & DAY & 14.7 & 1.59 & & 0.70 & 0.78 \\
\hline 21 Mar & NIGHT & 1.9 & 0.60 & & 0.75 & 1.07 \\
\hline 23 Mar & DAY & 15.3 & 2.24 & & 0.72 & 0.83 \\
\hline 23 Mar & NIGHT & 8.9 & 1.34 & & 0.86 & 0.99 \\
\hline 25 Mar & DAY & 11.0 & 2.05 & & 0.84 & 1.02 \\
\hline $25 \mathrm{Mar}$ & NIGHT & 3.6 & 0.85 & & 0.63 & 0.81 \\
\hline 27 Mar & DAY & 10.1 & 1.53 & & 0.50 & 0.57 \\
\hline 27 Mar & NIGHT & 2.5 & 0.80 & & 0.60 & 0.86 \\
\hline
\end{tabular}

${ }^{1}$ Sampling time period corresponds to 06:00-18:00 LT for DAY filters, to 18:00-06:00 for NIGHT filters, and to 09:00 to 09:00 LT for daily-averaged filters.

${ }^{2} \mathrm{EC}$ (BC) data used at T0 for the US data are from Aethalometer measurements for the time period before $17 \mathrm{March}$, and from EC real-time measurement afterwards. For the Swiss filters EC are from filter measurements. At $\mathrm{T} 1$ all data are from direct real-time measurements of EC.

${ }^{3} f_{\mathrm{NF}}$ are corrected for the bomb effect, assuming that current values are $11 \%$ overpredicted (see text for details)

${ }^{4}$ The fraction of modern carbon in $\mathrm{BC}$ is assumed to be $5 \%$ for the US dataset.

shown in Fig. S1 (see Supplement). It should be noted that the different EC concentrations measured either directly or derived from aerosol light absorption measurements (often referred to as black carbon or "BC") agree reasonably well at both T0 and T1. Paredes-Miranda et al. (2009) showed that the different $\mathrm{BC}$ measurements also agreed well at $\mathrm{T} 0$. Since at T0 only low time resolution measurements of EC are available (12 or $24 \mathrm{~h}$ ), a combination of measurements was used to produce a high-resolution EC surrogate, using the thermal-optical Sunset labs analyzer data from Stone et al. (2008), and the aethalometer measurements of BC by Marley et al. (2009). At T1 the thermal-optical measurements of EC were used, which have 1-h time resolution (de Gouw et al., 2009). For some filters, the estimated $f_{\mathrm{M}}^{\mathrm{OC}}$ exceeds 1 . This is however physically possible as discussed above due to the nuclear bomb excess.

In their samples, Marley et al. (2009) did not correct for the enrichment of ${ }^{14} \mathrm{C}$ due to nuclear bomb radiocarbon, which results in the reported $f_{\mathrm{M}}$ being larger than $f_{\mathrm{NF}}$ by approximately 1.16 for wood burning emissions and 1.055 for biogenic aerosols (Szidat et al., 2009b). Assuming that the modern carbon content for biomass burning is similar to the factor of 1.16 for wood burning samples analyzed by Szidat et al. (2009) is reasonable as the wildfires that took place in pine forests in mountains and hills near the city are thought to dominate biomass burning OA in Mexico City during MILAGRO (e.g. Yokelson et al., 2007; Aiken et al., 2010). To estimate the non-fossil carbon fraction $\left(f_{\mathrm{NF}}\right)$ contained in OC we correct for this effect by using an average value of 1.1 under the assumption that modern carbon comes in equal proportions from sources with similar ages as wood and recently photosynthesized biogenic material (Table 3). Since the extreme values for this parameter are thought to be 1.16 for wood burning and 1.065 for biogenic SOA, we estimate the sensitivity of the results to the choice of this parameter as a few percent.

Finally, for some samples the estimated values of $f_{\mathrm{NF}}^{\mathrm{OC}}>1.0$. This may be due to measurement noise, and suggest that the contribution of noise to scatter in the US data is likely to be at least 0.10 . Alternatively, perhaps the assumptions for converting $f_{\mathrm{M}}$ into $f_{\mathrm{NF}}$ are too conservative (too low assumed average $f_{\mathrm{M}} / f_{\mathrm{NF}}=1.10$ ) for the whole dataset or for some samples with high biomass burning impact. A third option is that the assumed value of $f_{\mathrm{NF}}^{\mathrm{EC}}$ may be too low for some samples. As the EC concentration is only $\sim 1 / 4$ of TC, the uncertainty range of $0.13-0.04=0.09$ for $f_{\mathrm{NF}}^{\mathrm{EC}}$ (from Table 3 ) will only cause an uncertainty of 0.03 in the estimated $f_{\mathrm{NF}}^{\mathrm{OC}}$. Given the much larger uncertainties in the measurements and model, we have not considered this effect directly in the rest of the manuscript.

\subsection{Estimates of $f_{\mathrm{NF}}$ in $\mathrm{PM}_{10} \mathrm{OC}$ at the urban site}

The second dataset (called "Swiss dataset") consists of four $\mathrm{PM}_{10}$ filters collected at the urban T0 site (Aiken et al., 2010) during (1) 21 March 09:04 a.m.-22 March 09:05 a.m., (2) 22 March 09:20 a.m.-23 March 09:20 a.m., (3) 26 March 09:40 a.m.-27 March 09:40 a.m., (4) 29 March 11:04 a.m.30 March 11:05 a.m. The filters were analyzed directly for modern carbon content in EC and OC. Details of the analyses are described by Aiken et al. (2010). Although only four 24-h filters are available, they were collected and analyzed completely independently, and thus are extremely valuable to compare to the Marley et al. (2009) data reported at the same 
site. Furthermore, the direct separation for ${ }^{14} \mathrm{C}$ analysis into $\mathrm{OC}$ and EC is of special importance for source apportionment, as both carbonaceous particle fractions originate from different sources. $f_{\mathrm{NF}}$ was estimated from the $f_{\mathrm{M}}$ measurements using the same convention as above.

\subsection{TC and OA component analysis}

TC filter measurements were performed simultaneously as part of the ${ }^{14} \mathrm{C}$ measurements (Table 3 ). The reported values corresponding to the US dataset vary from $10-25 \mu \mathrm{gC} \mathrm{m}^{-3}$ at $\mathrm{T} 0$ and from $3-20 \mu \mathrm{gC} \mathrm{m}^{-3}$ at $\mathrm{T} 1$ with a few exceptionally elevated values at T0 on 11 March $\left(30 \mu \mathrm{gC} \mathrm{m}^{-3}\right)$, and at $\mathrm{T} 1$ on 9 and 13 March $\left(30\right.$ and $\left.96 \mu \mathrm{gCm}^{-3}\right)$. TC peak values $\left(>30 \mu \mathrm{gC} \mathrm{m}^{-3}\right.$ ) correspond most likely to local biomass burning events, which however have not been recorded by any other instrument operating at T0 and T1 during MILAGRO.

AMS data were acquired at the T0 and T1 supersites. Experimental details, intercomparisons to other instruments, and the methodology and results of the component analysis using positive matrix factorization (PMF, Ulbrich et al., 2009) are presented in Aiken et al. (2008, 2009, 2010), Paredes-Miranda et al. (2009); Huffman et al. (2009) and de Gouw et al. (2009). The main components determined by PMF are hydrocarbon-like OA (HOA), a surrogate for primary combustion OA; biomass-burning OA (BBOA), thought to be dominated by primary biomass burning OA; and oxygenated OA (OOA), a surrogate for SOA from all sources (see Table 2).

\section{Modeling approach}

\subsection{Model description}

For this study, the mesoscale chemical transport model CHIMERE was run from 11 to 31 March 2006 over the Mexico City region at both regional $\left(35 \times 35 \mathrm{~km}^{2}\right)$ and urban $\left(5 \times 5 \mathrm{~km}^{2}\right)$ grid scales using the same configuration and the same forcing (i.e. meteorology, emissions, boundary and initial conditions) as described by Hodzic et al. (2009, 2010). Here we provide a brief summary of key sources and processes that influence the amount of modeled carbonaceous aerosols.

The CHIMERE model simulates the emissions of primary EC and OA, the chemistry and gas/aerosol partitioning of secondary organic species and their gaseous precursors, in addition to their transport, boundary layer mixing, and dry and wet deposition processes. Similar to Hodzic et al. (2009, 2010), primary gaseous and aerosol species arise from (i) anthropogenic sources as reported by the 2002 official Mexico City Metropolitan Area (MCMA) emission inventory (CAM, 2004) and the National Emissions Inventory (NEI) of 1999 emissions outside of the city (http://mexiconei. blogspot.com/), (ii) biomass burning emissions as estimated from satellite data by Wiedinmyer et al. (2006), (iii) biogenic VOC emissions calculated online using the MEGAN model (Guenther et al. 2006), and (iv) PBAP from fungal spores. The PBAP emissions had not been included in our previous studies and were calculated following the emission algorithm of Heald and Spracklen (2009). The formation of secondary organic species from traditional anthropogenic and biogenic precursors (i.e. volatile organic compounds, VOCs) is modeled as by Pun et al. (2006). As described by Hodzic et al. (2010), the model also includes the gas-phase chemistry and partitioning of semi-volatile and intermediatevolatility primary organic vapors (SVOC and IVOC, or together as S/IVOC) based on two alternative parameterizations: the first proposal of Robinson et al. (2007), and the updated parameterization from Grieshop et al. (2009). The carbon (OC) and oxygen fractions for each S/IVOC lumped species are explicitly modeled according to the specifications of the Robinson and Grieshop parameterizations. In addition to carbonaceous species, CHIMERE accounts for windblown dust, secondary inorganic species (sulfate, nitrate and ammonium), particulate water, and other primary anthropogenic particles. The size distribution of all species is represented using a sectional approach with 8 size bins $(40 \mathrm{~nm}$ to 10 microns in physical diameter) with internal mixing within each bin. Further information on the model formulation can be found on http://www.lmd.polytechnique.fr/chimere.

\subsection{Non-fossil OC estimation from the model results}

The model simulates OA mass concentrations, which in addition to OC also include oxygen, hydrogen and nitrogen mass. Therefore, the $\mathrm{OC}$ concentration at each point in space and time arising from source $i\left(\mathrm{OC}_{i}\right)$ is estimated from the predicted OA concentration for that source $\left(\mathrm{OA}_{i}\right)$ as:

$\mathrm{OC}_{i}\left(\mu \mathrm{gCm}^{-3}\right)=\frac{\mathrm{OC}_{i}\left(\mu \mathrm{gCm}^{-3}\right)}{(\mathrm{OM} / \mathrm{OC})_{\mathrm{i}}}$

where $(\mathrm{OM} / \mathrm{OC})_{i}$ represents the source-specific ratio of total $\mathrm{OA}$ to $\mathrm{OC}$ concentrations. The term OM/OC is retained here for consistency with most of the previous literature, even though the term OA/OC would be more consistent with the terminology of this paper. The value of OM/OC for ambient particles depends on the source and the degree of oxidation of the aerosol. Recent studies have reported values of 1.6 and 2.1 for mixed $\mathrm{OA}$ at urban and rural sites, respectively (Turpin and Lim, 2001; Aiken et al., 2008). In this study, we use source-specific OM/OC ratios from Aiken et al. (2009) measured in Mexico City for the surrogates of anthropogenic combustion POA (1.38), biomass burning POA (1.55), and total SOA (1.95). For biogenic SOA formed in a smog chamber Shilling et al. (2009) reported an OM/OC of 1.6 at the OA levels in Mexico City ( $\sim 20 \mathrm{~g} \mathrm{~m} \mathrm{~m}^{-3}$, Aiken et al., 2009). Here we use a value of 1.7 for biogenic SOA to conservatively account for additional aging that occurs in the atmosphere and is not fully captured in smog chambers (Aiken et al., 2008; 
$\mathrm{Ng}$ et al., 2010). The OC content in the SOA formed from S/IVOC was directly determined from modeled species as both carbon and oxygen fractions are explicitly modeled.

The model allows separate tracking of POA and SOA concentrations resulting from various sources including urban emissions, biomass burning, biogenic or PBAP emissions. Once the OC concentrations arising from all modeled OA sources are calculated at a given point in space and time, the fraction of non-fossil carbon $f C_{\mathrm{NF}}^{\mathrm{OC}}$ is derived according to the following equation:

$$
\begin{aligned}
& f C_{\mathrm{NF}}^{\mathrm{OC}}= \\
& \frac{\mathrm{SOC}_{\mathrm{BSOA}}+\mathrm{POC}_{\mathrm{BB}}+\mathrm{SOC}_{\mathrm{BB}}+\mathrm{POC}_{\mathrm{PBAP}}+0.2 \times\left(\mathrm{POC}_{\mathrm{urb}}+\mathrm{SOC}_{\mathrm{urb}}\right)}{\sum_{i} \mathrm{OC}_{i}}
\end{aligned}
$$

where $\mathrm{SOC}_{\mathrm{BSOA}}$ is the $\mathrm{OC}$ in biogenic $\mathrm{SOA}$, and the last term estimates the impact of non-fossil carbon emissions from urban sources, due to the impact of sources such as food cooking, tire and brake wear, resuspended road dust, trash burning, biofuel use, cigarette smoke, etc. (Hildemann et al., 1994; Christian et al., 2010). It is assumed that $\sim 20 \%$ of the carbon from urban sources is non-fossil, as an average of the values determined by Hildemann et al. (1994) for the Los Angeles basin. A rough estimate of this ratio in Mexico City based on the MCMA emission inventory and the sourcespecific non-fossil contributions determined by Hildemann et al. (1994) suggests that about $18 \%$ of the total urban OC emissions should be considered as non-fossil, which may be a lower limit since the emission inventory does not properly account for sources such as trash burning and biofuel use (Christian et al., 2010). This parameter is very uncertain and further research should be aimed at its quantification. The sensitivity of our results to this parameter is examined in Sect. 4.4.1.

The OC associated with biomass burning, biogenic SOA and PBAP emissions is considered fully as non-fossil. However, it should be noted that biogenic and biomass burning emissions do not always result from natural activities. For example agricultural crops emit biogenic VOCs, and burning of agricultural residues, prescribed or arson-related wildfires are anthropogenic sources of modern carbon. It has also been suggested that biogenic SOA formation may be more efficient when biogenic VOCs mix with anthropogenic pollution due to perhaps higher oxidants, $\mathrm{POA}, \mathrm{NO}_{\mathrm{x}}$, or acidity (de Gouw et al., 2005; Weber et al., 2007; Carlton et al., 2008; de Gouw and Jimenez, 2009). Thus one should not equate "non-fossil OC" with "OC from natural emissions" or "uncontrollable OC".

Carbonates can also be a source of fossil or non-fossil carbon. It is necessary to distinguish between dust-related carbonates that are fossil, vs. marine carbonates that are nonfossil. In Mexico City at T0 there were about $0.46 \mu \mathrm{gC} \mathrm{m} \mathrm{m}^{-3}$ from carbonate (Querol et al., 2008), which is 3\% of the total carbon in $\mathrm{OC}+\mathrm{EC}$. The non-fossil contribution from marine origin is likely negligible in this region. In addition, it is reasonable to consider that $\mathrm{OC}$ analysis should be minimally affected by carbonates as some of the carbonates are not dissolved by the $\mathrm{HNO}_{3}$ digestion used in this analysis (hydrofluoric acid digestion is needed for full dissolution) and the $\mathrm{CO}_{2}$ release from most carbonates needs higher temperatures than those used in this analysis. Overall the error introduced by carbonates in the analyses of the Swiss dataset is estimated to be less than $1 \%$. Thus in the model, the contribution of carbonates is not considered.

\subsection{Model application during MILAGRO}

Results of three model simulations are discussed here. The main focus of this paper is on the results from the "ROB" and "GRI" simulations. These simulations include SOA formation from traditional VOC precursors, and also explicitly treat SOA formation from aging of primary organic S/IVOC following the approaches by Robinson et al. (2007) and Grieshop et al. (2009), as discussed by Hodzic et al. (2010). These two simulations are also compared to the reference ("REF") simulation from Hodzic et al. (2009) where SOA is only formed from VOCs using a traditional two-product model, and in which POA is assumed to be inert and non-volatile.

For comparison with measurements, the simulated parameters are spatially and temporally interpolated at the location of the measurement sites. The first day of the simulation corresponds to the "spin-up" time and the model results are analyzed from 12 to 31 March. Measured and predicted concentrations of all species are reported under ambient conditions of pressure and temperature; mass concentrations should be multiplied by about 1.42 for conversion to STP conditions (1 atm, $273 \mathrm{~K}$ ).

The CHIMERE model was recently evaluated against meteorological and gas-phase observations of the MIRAGE field study (Hodzic et al., 2009), and also used to examine OA formation pathways in the Mexico City region by anthropogenic and biogenic traditional precursors (Hodzic et al., 2009), as well as primary semi-volatile organic vapors (Hodzic et al., 2010).

\section{Results and discussion}

\subsection{Model-Measurement Comparison for $f_{\mathrm{NF}}^{\mathrm{TC}}$}

Figure 2 compares the predicted and observed fractions of non-fossil carbon contained in carbonaceous aerosols for the REF, ROB, and GRI simulations. The observed values from both datasets range from 0.24 to 0.67 within the city and from 0.50 to 0.86 downwind (Table 3 ), suggesting that fossil sources are major contributors to TC within Mexico City, whereas biogenic and biomass burning contributions represent a larger fraction $20 \mathrm{~km}$ downwind of the city center.

The model $f_{\mathrm{NF}}^{\mathrm{TC}}$ results are quite consistent (with some scatter) with the Swiss data. As $f_{\mathrm{NF}}^{\mathrm{TC}}$ is about 0.15 larger 

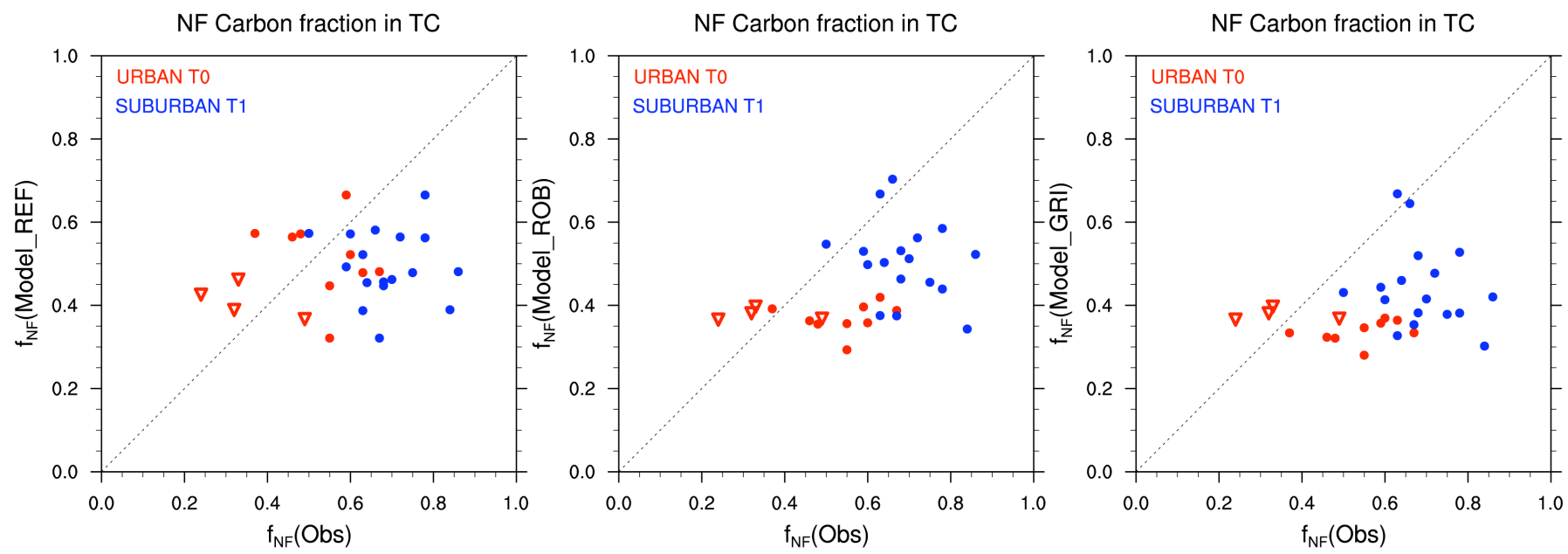

Fig. 2. Comparisons of predicted and observed non-fossil carbon fractions $\left(f_{\mathrm{NF}}\right)$ determined for Total Carbon filters. The submicron US filters are represented by dots, while $\mathrm{PM}_{10}$ Swiss filters are indicated by the triangles. Modeled values are based on REF (left), ROB (middle) and GRI (right) simulations. Both US and Swiss datasets have been corrected for effects of historical nuclear bomb testing (see text for details).

for the $\mathrm{PM}_{1}$ US dataset compared to the $\mathrm{PM}_{10}$ Swiss dataset, the model shows a similar discrepancy vs. the US dataset, with the model having lower $f_{\mathrm{NF}}^{\mathrm{TC}}$ by $\sim 0.15$ at both sites, again consistent across the REF, ROB and GRI simulations. The variability of $f_{\mathrm{NF}}^{\mathrm{TC}}$ in the model at the urban site is much lower than observed for both the Swiss and US datasets. No increase in $f_{\mathrm{NF}}^{\mathrm{TC}}$ between urban and suburban locations is seen in the REF simulation vs. 0.15 in the US measurements, while the ROB and GRI simulations capture the difference between the urban and suburban sites better. Model results also show that the choice of the SOA formation mechanism significantly impacts the modeled $f_{\mathrm{NF}}^{\mathrm{TC}}$ values. As discussed in Hodzic et al. (2009, see Fig. 11) the traditional approach can predict biogenic SOA fairly well when compared to specific tracers, which is consistent with studies at other locations. However SOA formation associated with urban emissions is severely underpredicted by the REF simulation leading to a larger relative fraction of non-fossil TC within the city for the wrong reasons. The GRI simulation produces 0.05-0.1 lower $f_{\mathrm{NF}}^{\mathrm{TC}}$ (more fossil aerosol) than ROB due to differences in the precursor and mechanism details. As the results of ROB and GRI simulations are very similar (within $10 \%$ ) in terms of $f_{\mathrm{NF}}^{\mathrm{TC}}$ and the ROB simulation predicts $\mathrm{OA}$ concentrations slightly better during MILAGRO (Hodzic et al., 2010), in the rest of the paper we will only focus on the analysis of the ROB simulation.

Figure 2 also shows a surprisingly large difference between the two sets of measurements with a substantially lower non-fossil OC fraction for Swiss filters, as already discussed by Aiken et al. (2010). Although sampling times were not coincident for the two sets of data, the average $f_{\mathrm{NF}}^{\mathrm{TC}}$ value for Swiss filters (0.34) is much lower than the one for US (0.54). The main known difference between the two sets of filters is their size cut, with a $\mathrm{PM}_{10}$ cut for the Swiss data and a $\mathrm{PM}_{1}$ cut for the US filters. However this factor is unlikely to explain the difference as the amount of $\mathrm{OC}$ in coarse particles is very small (Querol et al., 2008; Aiken et al., 2010). The coarse mode is dominated by crustal particles, and likely contains some vegetative detritus (Stone et al., 2008) or PBAP (see below) that would contribute to measured non-fossil carbon. Paved road dust and break wear also contribute to the supermicron mode but have a large fraction of modern OC (Hildemann et al., 1994). The contribution of carbonates can be neglected for Mexico City as already discussed in Sect. 3.2. In the following some possible reasons for discrepancies found between the two sets of observations, and between the model and US observations will be discussed.

\subsection{Primary Biological Aerosol Particles (PBAP)}

The presence of PBAP in supermicron particles could be a reason for differences in $f_{\mathrm{NF}}^{\mathrm{TC}}$ for $\mathrm{PM}_{1}$ vs. $\mathrm{PM}_{10}$, although in the opposite direction as observed. For the comparisons with the Swiss dataset presented in Fig. 2 and also below, the modeled $f_{\mathrm{NF}}$ values were calculated for $\mathrm{PM}_{10}$ aerosols, and PBAP were included. PBAP have been found to contribute to the global budget of OA (e.g. Mahowald et al., 2008). Recently, Heald and Spracklen (2009) estimated the contribution of fungal spores as $23 \%$ of total primary OA emissions, or $7 \%$ of the fine-mode source. In this study PBAP emissions were calculated as a function of leaf area index (LAI, $\mathrm{m}^{2}$ of leaf surface per $\mathrm{m}^{2}$ of ground surface) and water vapor mixing ratios $\left(\mathrm{H}_{2} \mathrm{O}_{\text {vap }}\right.$ dimensionless) following the emission algorithm from Heald and Spracklen (2009) (C. Heald, personal communication, 2009): $\quad E_{\text {PBAP }}\left(\mathrm{g} \mathrm{m}^{-2} \mathrm{~s}^{-1}\right)=\alpha \times \mathrm{LAI} \times \mathrm{H}_{2} \mathrm{O}_{\text {vap }}$ where $\alpha$ equals $5.18 \times 10^{-8}$ and $1.55 \times 10^{-7} \mathrm{~g} \mathrm{~m}^{-2} \mathrm{~s}^{-1}$ for $\mathrm{PM}_{2.5}$ and $\mathrm{PM}_{10}$ respectively. Figure 3 shows the spatial distribution of 

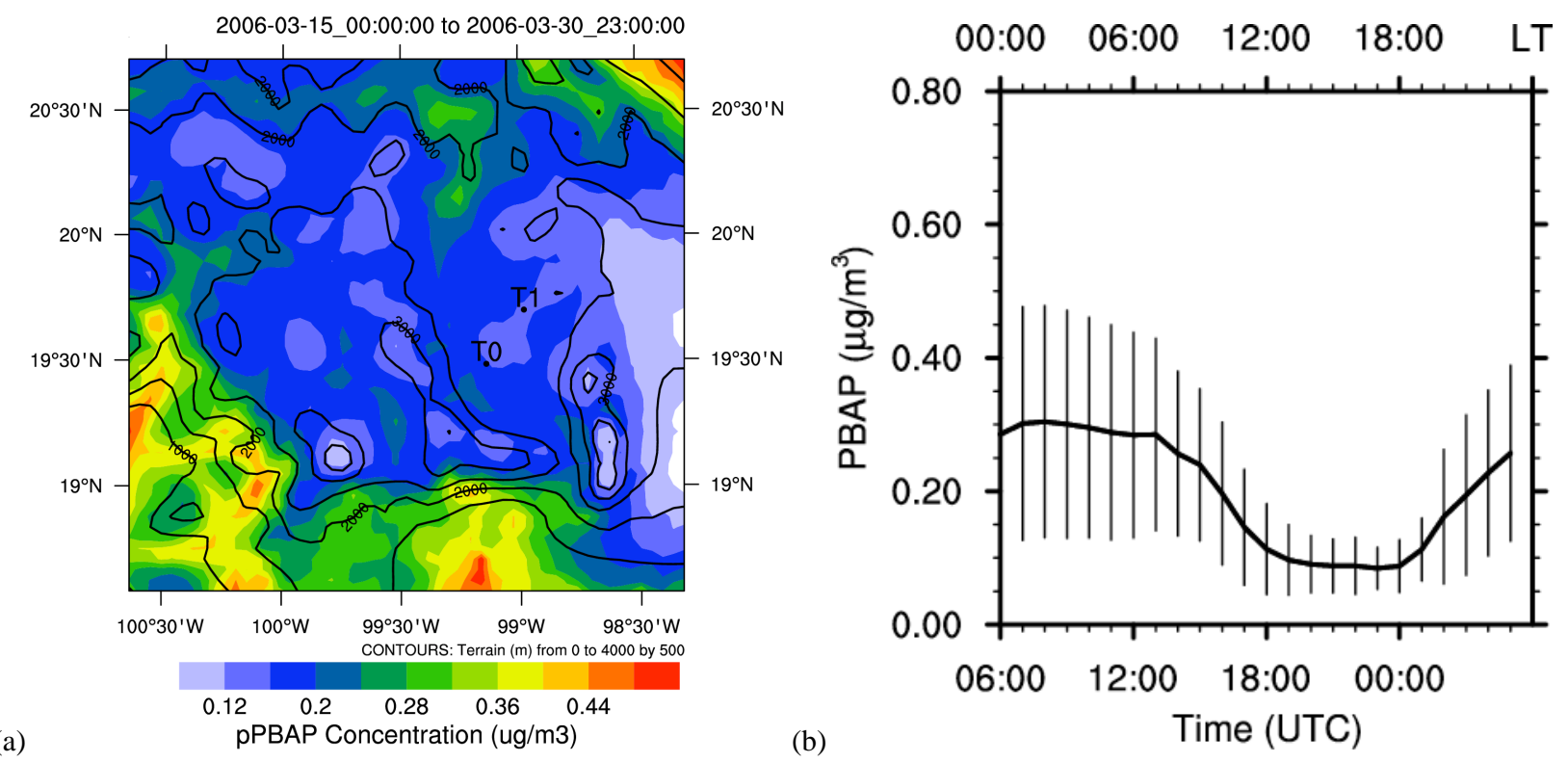

Fig. 3. (a) Spatial distribution and (b) average diurnal profile at the urban $\mathrm{T} 0$ site of primary biological particles $\left(\mathrm{PBAP}, \mu \mathrm{gC} \mathrm{m}^{-3}\right)$ as simulated by the model over the Mexico City area between 15 and 31 March 2006.

the predicted average PBAP in the vicinity of Mexico City from 15-30 March 2006. Within the city basin the average values are close to $0.2 \mu \mathrm{g} \mathrm{m}^{-3}$. These concentrations are similar to the average concentrations predicted by Heald and Spracklen (2009) using GEOS-Chem. However, greater variability is found during the day, with minimum values in range $0.05-0.1 \mathrm{~g} \mathrm{~m} \mathrm{~m}^{-3}$ in the early afternoon, and high values in range $0.3-0.4 \mu \mathrm{g} \mathrm{m}^{-3}$ at night. It should be noted that this average PBAP concentration of $0.2 \mu \mathrm{g} \mathrm{m}^{-3}$ is about 10$15 \%$ of the estimated biogenic SOA $\left(\sim 1.5 \mu \mathrm{g} \mathrm{m}^{-3}\right.$, Hodzic et al., 2009) and therefore is not expected to dominate the non-fossil OC fraction. The presence of PBAP cannot explain, but also does not greatly increase, the differences in $f_{\mathrm{NF}}^{\mathrm{TC}}$ between the two sets of filters.

\subsection{Assessment of carbonaceous aerosol predictions}

Another possible reason for model disagreement with measured $f_{\mathrm{NF}}^{\mathrm{TC}}$ could be the errors in the EC or OC simulations in this region. The measured $f_{\mathrm{NF}}^{\mathrm{TC}}$ presented in Fig. 2 accounts for both EC and OC, so the model ability to simulate both carbonaceous aerosol components within Mexico City must be evaluated. This is first examined using real-time measurements of BC and OA. Because non-fossil carbon samples are available for $12 \mathrm{~h}$ day- and nighttime intervals (US dataset), here we compare the corresponding $12 \mathrm{~h}$-averaged predictions. This comparison is intended to complement the evaluation of predicted POA and SOA time series for March 2006 presented in our previous work (Hodzic et al., 2010), focusing here on the specific time periods that are relevant to ${ }^{14} \mathrm{C}$ measurements, and including the comparison of $\mathrm{EC}$ which was not presented before.

\subsubsection{Comparison with EC measurements}

Observed and predicted concentrations of elemental carbon (EC) are shown in Fig. 4. The comparison of EC diurnal profiles at T0 indicates that the modeled values are a factor of 2 lower during the morning peak, and that this gap is somewhat reduced in the afternoon and eliminated overnight. The comparison performed for US dataset sampling periods confirms the model underprediction for many filters, especially at T0. Similar model behavior is encountered at the T1 site. Our results are consistent with those of Fast et al. (2009) and this error is most likely due to a too low emission inventory of EC as discussed in Fast et al. (2009). The better prediction overnight does not contradict that conclusion, as it most likely results from cancellation of errors as the too low EC emissions are balanced by the too low mixing layer in the model (Fast et al., 2009; Hodzic et al., 2009). If the model underprediction of EC was rectified (e.g. by increasing EC emissions by a factor of 2 ), the simulated $f_{\mathrm{NF}}^{\mathrm{TC}}$ would decrease on average by about 0.02 as $f_{\mathrm{NF}}^{\mathrm{EC}}$ is only $0.04-0.13$ (Table 3).

\subsubsection{Comparison with OC measurements}

The model skill in predicting OA was examined with the high time-resolution data and model results by Hodzic et al. (2009, 2010), and is re-examined using OC and specifically for the filter period averages in Fig. 5. At the urban T0 site, the observed AMS daytime (nighttime) OC concentrations vary from 8 to $20 \mu \mathrm{gC} \mathrm{m}^{-3}\left(3-17 \mu \mathrm{gC} \mathrm{m}^{-3}\right)$ with rather low values found during the more ventilated periods of e.g. 19-20 March and higher levels observed during 

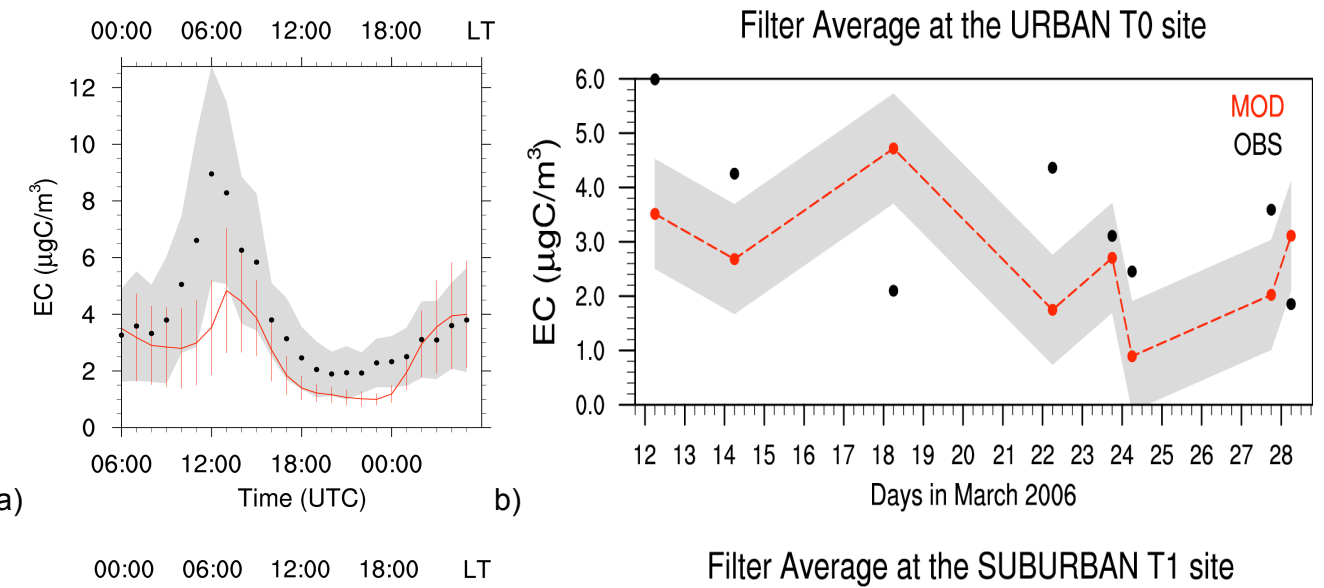

Filter Average at the SUBURBAN T1 site
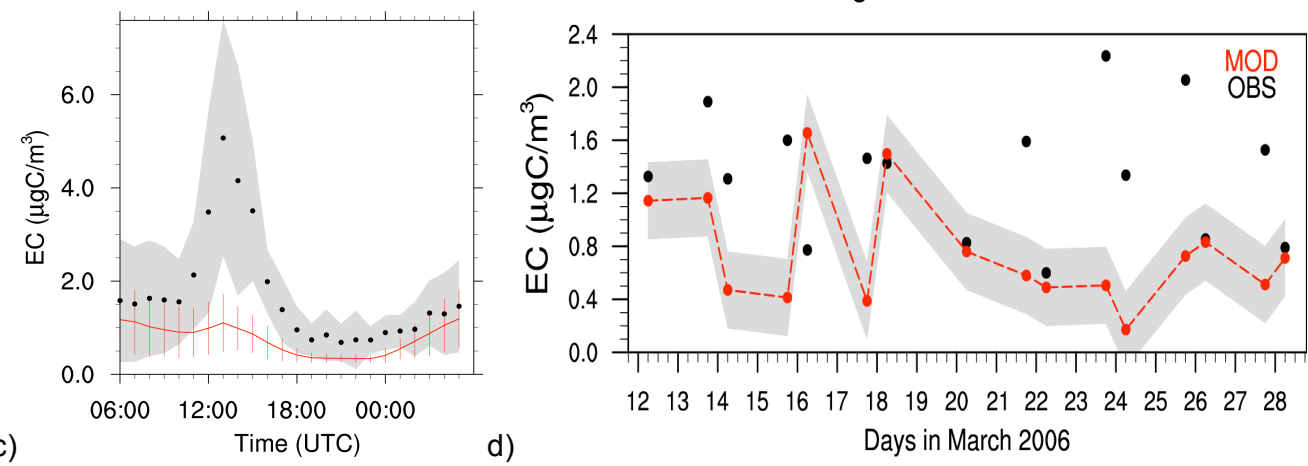

Fig. 4. Comparison of EC diurnal profiles (left panels: a, c) and averaged EC concentrations (right panels: $\mathbf{b}$, d) for the $\mathrm{PM}_{1} \mathrm{US}_{\mathrm{S}}$ samples as predicted by the CHIMERE model (red line) and as measured (black dots, Aethalometer-Marley, OCEC Doran, see Fig. S1) at the URBAN and SUBURBAN sites. Sampling time periods are given in Table 3. In plots b and d, model values are given only for available US dataset points to allow a more focused comparison with radiocarbon data.

more stagnant days e.g. 16, 21, 22 or 30 March (Fast et al., 2009; Hodzic et al., 2009). On most days, SOC contributes between 40 and $60 \%$ of the total OC (not shown). Both model runs capture relatively well the observed temporal relative variations, with the exception of the high daytime value observed on the 18th or the nighttime one from the 20th March. These peak values coincide with intense advection of biomass burning plumes from nearby wildfires (Aiken et al., 2009) that are generally underpredicted in the model as discussed by Hodzic et al. (2010). The predicted OC from the ROB simulation is in a reasonable agreement with observed values i.e. within $10-30 \%$ most of the time. The REF model simulation using the traditional SOA approach predicts substantially lower OC levels because of a severe underprediction of SOA from anthropogenic and biomass burning sources (not shown here, see Hodzic et al., 2009, 2010).

At the suburban T1 site, OC modeling appears to be more challenging, as already discussed by Hodzic et al. (2010). The underprediction by the REF simulation is more severe (by about a factor of two), and there is more scatter between the model and the observations. A reasonable agreement is obtained for the ROB simulation especially during the day, with the exception of the 15-16 March when the dispersion of pollutants in the model is too low (Hodzic et al., 2010). Some underpredictions are observed in some cases of wildfire impacts (e.g. the night of 18 March and 23 March daytime).

The important result of these comparisons is that the ROB simulation provides a fairly reasonable mass closure for OC in particular within the city, which is a requirement that needs to be met before examining the model ability to predict the relative proportions of fossil and non-fossil OC. One should also keep in mind that for a few high biomass burning events that are not captured by the model (e.g. daytime filter on the 21 st at T0), the model is likely to underpredict the $f_{\mathrm{NF}}^{\mathrm{OC}}$ for those particular filters.

\subsection{Fossil and non-fossil contributions to OC}

Now that we have established the reasonable model skill in predicting OC levels, we focus on determining whether or not the predicted non-fossil OC fraction is reasonable, as shown in Fig. 6. Good agreement with measurements is observed for the Swiss dataset. The observed $f_{\mathrm{NF}}^{\mathrm{OC}}$ varies from 0.37 to 0.55 within the city, and show less day-to-day variability than the US data. The differences among the four 

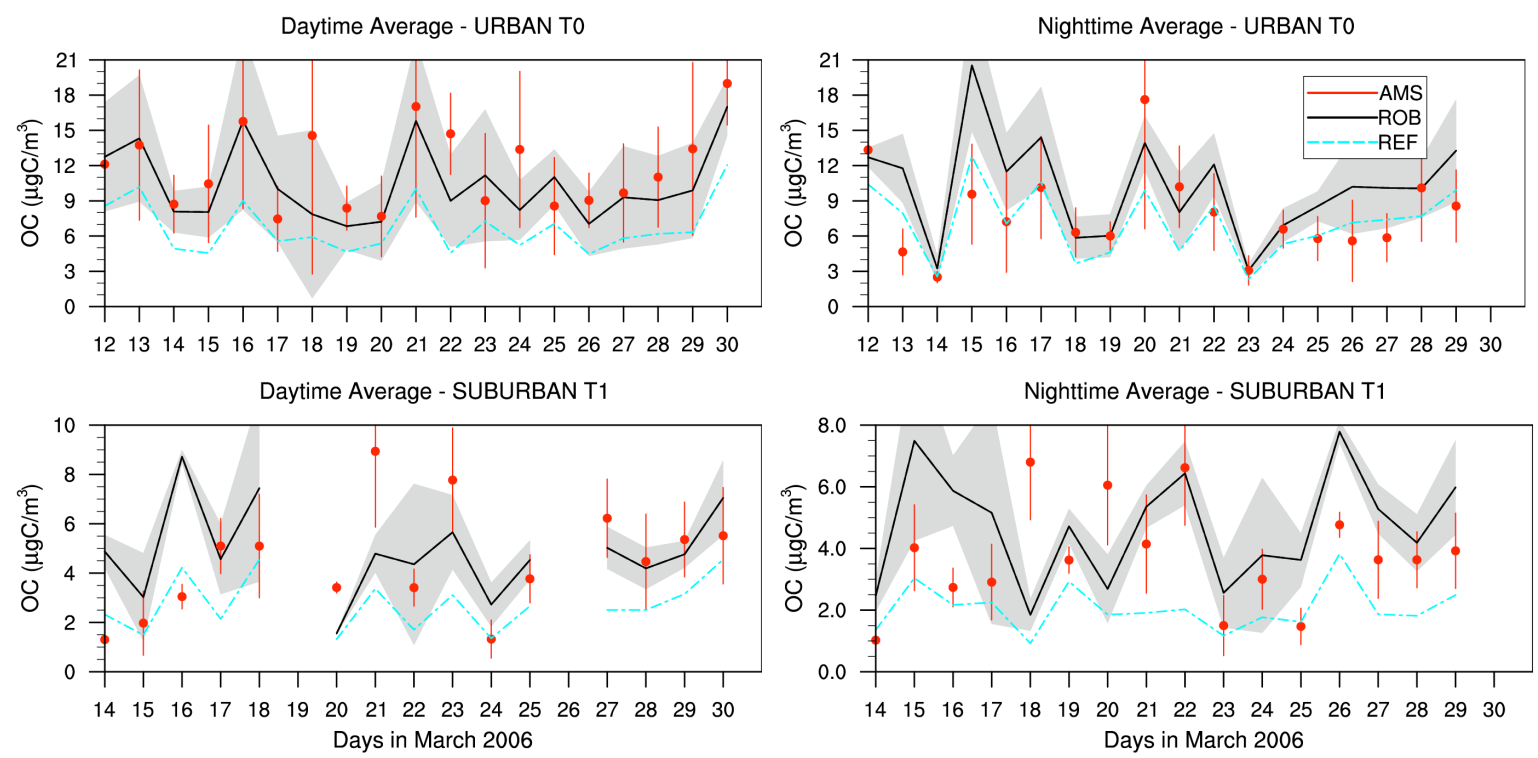

Fig. 5. Comparison of day- and nighttime averaged concentrations of submicron organic carbon particles as predicted by the CHIMERE model for the ROB (black line) and REF (blue line) simulations, and as measured by the AMS instrument (red dots) at the urban (T0) and suburban (T1) sites. The variability ( \pm 1 sigma) around the average value is also indicated for both modeled (grey area) and observed (vertical bars) values. Day- and nighttime averaging intervals correspond to submicron radiocarbon sampling periods given in Table 3.

Swiss filters are thought to be mainly due to variability in BBOA impacts (Aiken et al., 2010). Higher $f_{\mathrm{NF}}^{\mathrm{OC}}$ values $(0.47$ and 0.55 ) for the first two samples correspond to higher fire impact period (as shown by higher BBOC values, Hodzic et al., 2010, Figs. 2-3), and feature $0.10-0.15$ higher $f_{\mathrm{NF}}^{\mathrm{OC}}$ values than filters from 26 and 29 March $\left(f_{\mathrm{NF}}^{\mathrm{OC}}\right.$ of 0.37 and 0.40) taken during lower fire influence. However, it should be noted that the $f_{\mathrm{NF}}^{\mathrm{TC}}$ and $f_{\mathrm{NF}}^{\mathrm{EC}}$ for these filters show a clear fire signature only for the first day (21 March), with higher values by 0.19 and 0.08 respectively than during the rest of the time which is dominated by fossil sources $\left(f_{\mathrm{NF}}^{\mathrm{TC}}<0.33\right.$ and $f_{\mathrm{NF}}^{\mathrm{EC}}<0.05$ ).

$\mathrm{PM}_{1} \mathrm{OC}$ at $\mathrm{T} 0$ as estimated from the US dataset has $f_{\mathrm{NF}}^{\mathrm{OC}}$ in the range $0.49-1.08$, whereas the values are even higher $(0.57-1.07)$ at the suburban location T1. As discussed in Sect. 2.2, the values of $f_{\mathrm{NF}}^{\mathrm{OC}}>1.0$ for some samples may be due to measurement noise, or the assumptions for converting $f_{\mathrm{M}}$ into $f_{\mathrm{NF}}$. At T0, nighttime values are slightly higher $\left(f_{\mathrm{NF}}^{\mathrm{OC}}\right.$ in range $\left.0.59-1.08\right)$ than during daytime (0.49-0.67) suggesting that background biogenic SOA, BBOA from smoldering fires, and other non-fossil sources are more important contributions at night. This is consistent with the results of Hodzic et al. (2009) that have already shown a higher relative contribution of biogenic SOA during nighttime when urban SOA and POA emissions from urban activities are at lower. BBOA peak values were also observed during the nighttime and early morning hours due to the advection of smoke from smoldering fires in the shallow nighttime boundary layer (Aiken et al., 2009; Hodzic et al., 2010). Also, the highest $f_{\mathrm{NF}}^{\mathrm{OC}}$ values, exceeding 1.0, were collected overnight on 21 March during high biomass burning impact events. Somewhat lower difference between day and nighttime values is observed at T1, e.g. 0.23 at T0 and 0.08 at T1 on average, due to a more limited urban influence. Similar to the $f_{\mathrm{NF}}^{\mathrm{TC}}$ comparison, the simulated $f_{\mathrm{NF}}^{\mathrm{OC}}$ are lower for the ROB simulation compared to the US dataset, as shown in Fig. 6. This gap is particularly pronounced at $\mathrm{T} 1$. The simulated $f_{\mathrm{NF}}^{\mathrm{OC}}$ range from 0.25 to 0.55 at $\mathrm{T} 0$, and up to 0.65 at $\mathrm{T} 1$ and are thus on average $0.20-0.30$ lower than the US dataset.

The origin of the high $f_{\mathrm{NF}}^{\mathrm{OC}}$ values reported for $\mathrm{PM}_{1} \mathrm{US}$ filters does not seem to find explanation in our modeling results. Unlike for the filter measurements, the predicted $f_{\mathrm{NF}}^{\mathrm{OC}}$ values for $\mathrm{PM}_{1}$ and $\mathrm{PM}_{10}$ aerosols are different by less than 0.02 (Fig. 6a). Thus the model difference between the predicted submicron and supermicron values cannot explain the large gap found between the two sets of filters. If the Swiss measurements were correct that would suggest that US measurements are likely biased towards high $f_{\mathrm{NF}}^{\mathrm{OC}}$ values.

The $f_{\mathrm{NF}}^{\mathrm{OC}}$ measurements were also combined with the measured or estimated OC concentrations (see Table 3) to estimate the absolute concentrations of fossil and non-fossil OC. The predicted fossil OC concentrations at both $\mathrm{T} 0$ and $\mathrm{T} 1$ sites are slightly lower than the Swiss data and higher than the US data at T0, while data and model are more consistent at T1. Non-fossil OC is somewhat underpredicted when compared to the Swiss data and shows a large underprediction at T1 with respect to US data. For T0 the lower fossil OC of the US dataset (vs. the model) is compensated by higher non-fossil OC than the model. At T1, where only the US dataset is available the non-fossil OC is higher by 

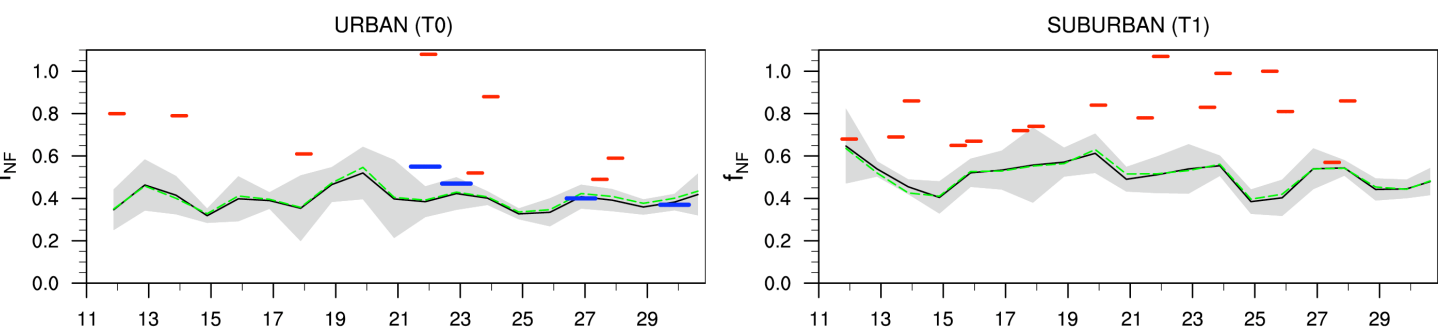

a)
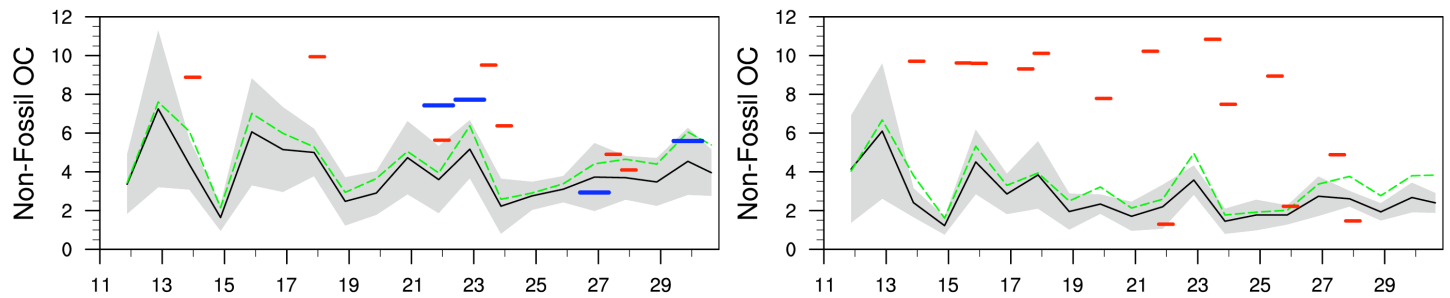

b)
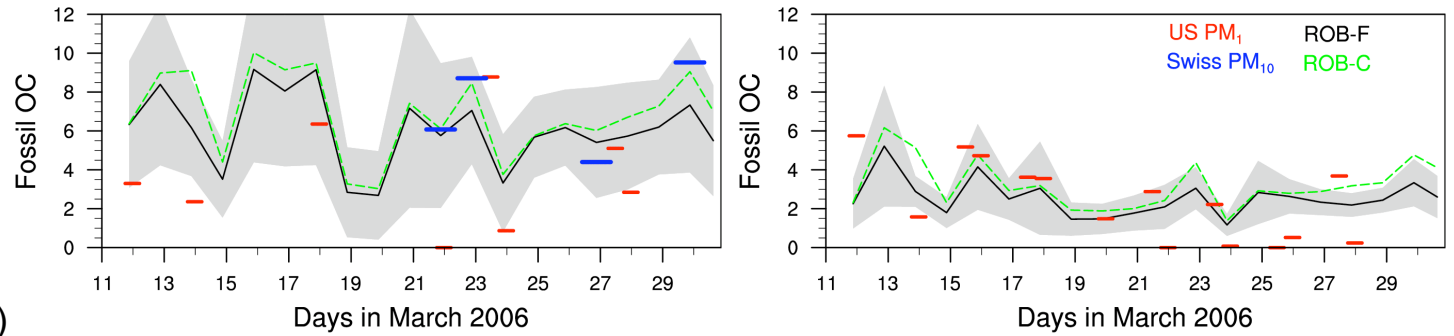

Fig. 6. (a) Fractions of non-fossil organic carbon $\left(f_{\mathrm{NF}}\right)$ and associated (b) non-fossil and (c) fossil OC concentrations $\left(\mu \mathrm{gC} \mathrm{m}^{-3}\right)$ as predicted by CHIMERE and derived from US (red) and Swiss (blue) filters measurements at the URBAN and SUBURBAN sites. Filter-sampling time frame is given in Table 3. Model outputs from the ROB simulation are daily-averaged from 09:00 to 09:00 LT (the consecutive day) for submicron (black line ROB-F) and $\mathrm{PM}_{10}$ (green line ROB-C) size distributions.

$5-8 \mu \mathrm{gC} \mathrm{m}{ }^{-3}$ compared to the model on most of the days. Given the reasonable agreement of the model with the observed AMS values shown on Fig. 5b, this comparison suggests inconsistencies between the $\mathrm{PM}_{1}$ OC filter data and the AMS measurements at T1.

Filters collected between 23 and 24 March during the low biomass burning period illustrate well these inconsistencies. Filter data seems to indicate an underprediction of the background non-fossil concentrations of about $4 \mu \mathrm{gC} \mathrm{m}^{-3}$, i.e. while fossil $\mathrm{OC}$ concentrations seem to match the observed values. As the biomass burning influence is very limited during this period within the city, a possible interpretation would be that biogenic emissions are substantially underpredicted. However this is not consistent with results reported by Hodzic et al. (2009) that showed a good general model agreement with measurement-based estimates of biogenic SOA. On some days the fossil OC derived from the submicron US filters is close to zero or zero, which seems unrealistically low for this suburban site located next to a highway, and is also contradictory with the presence of fossildominated EC. One should also keep in mind that day-to- day comparison of filters is a difficult task because the local meteorology plays an important role on the dispersion of pollutants within the boundary layer.

\subsubsection{Sensitivity analysis to urban emissions}

For the model results discussed above, we assumed that $f_{\mathrm{NF}}^{\mathrm{OC}}$ from urban emissions is 0.20 as an average of the values determined by Hildemann et al. (1994) for the Los Angeles basin. This fraction is uncertain and could vary highly from city to city. In particular it may be biased low for Mexico City where sources such as trash burning and biofuel use are not included in the emissions inventory. Therefore, here we test the model sensitivity to this assumption by considering lower and upper limits for $f_{\mathrm{NF}}^{\mathrm{OC}}$ of urban emissions of 0 and 0.40, as shown in Fig. 7. The lower limit of 0 is thought to be unrealistic but helps provide information on the modeled trend, while a value $\sim 0.30$ may be more realistic after accounting for the effects of biofuel use and trash burning (as discussed above), and 0.40 may be considered an upper limit. The comparison indicates a strong sensitivity to this parameter, with a near doubling of the modeled $f_{\mathrm{NF}}^{\mathrm{OC}}$ values 


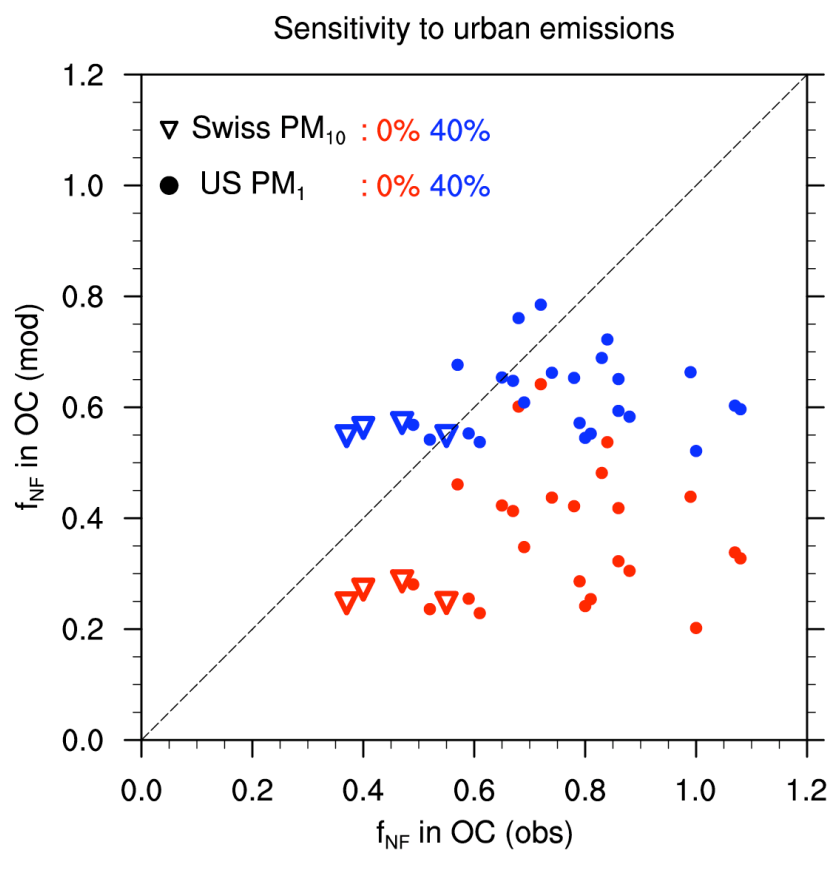

Fig. 7. Predicted (ROB) and observed $f_{\mathrm{NF}}$ for US (dots) and Swiss (triangles) datasets available during MIRAGE 2006 at T0 and T1. Model sensitivity to assumed fraction of modern carbon in urban anthropogenic emissions is tested: no modern carbon is assumed (lower limit = red color), and $40 \%$ modern carbon content in urban anthropogenic emissions is considered (upper limit = blue color).

when increasing the contribution of urban emissions from 0 to 0.40 . This is not surprising given the fact that urban sources are the major contributor to predicted OC in and near Mexico City (Hodzic et al., 2010). The predicted $f_{\mathrm{NF}}^{\mathrm{OC}}$ values for the Swiss filters increase from $0.25-0.30$ to $0.55-0.60$ for the extreme sensitivity cases, and are either 0.2 below the observed $f_{\mathrm{NF}}^{\mathrm{OC}}$, or 0.2 above it. The scatter in the comparison with the US data does not improve for most of the points although a factor of 2 higher $f_{\mathrm{NF}}^{\mathrm{OC}}$ is predicted when considering urban $f_{\mathrm{NF}}^{\mathrm{OC}}$ of 0.40 instead of 0 .

\subsubsection{Sensitivity analysis to biomass burning emissions}

The predicted amount of primary organic material originated from biomass burning is another uncertain parameter that could influence the modeled levels of non-fossil carbon. As shown in Hodzic et al. (2010) the biomass burning contribution is underpredicted at the urban site during MILAGRO, especially for nighttime and early morning intense plumes, which could result in an underprediction of the non-fossil carbon fraction. The likely reasons for the underestimation of biomass burning plumes is related to the model resolution $\left(5 \times 5 \mathrm{~km}^{2}\right)$ that cannot accurately represent subgrid fire plumes, the representation of smoldering emissions in the late evening and night (Aiken et al., 2010), and the limited accuracy of the wildfire emission inventories that do not account for fires not detectable in a $1 \mathrm{~km}$ satellite pixel. To estimate the impact of the underestimation of BBOA plumes on the ${ }^{14} \mathrm{C}$ budget, the modeled BBOA was replaced with the measured BBOA at the urban and suburban sites, whenever the measured values were larger than the modeled ones. The sensitivity to this correction is shown on Fig. 8. This effect increases the modeled ${ }^{14} \mathrm{C}$ by $\sim 5-10 \%$ during some ${ }^{14} \mathrm{C}$ sampling periods and reduces the differences with the measurements (Fig. 8a). The improved agreement between model and measurements is particularly noticeable for the two Swiss filters that were taken during periods influenced by increased fire activity and affected by early morning BBOA plumes (i.e. 21-22 March). The hourly comparison between the model results obtained with and without this correction during the entire MILAGRO campaign (Fig. 8 b) shows that only $10 \%$ of the modeled $f_{\mathrm{NF}}$ values are very sensitive to the representation of the biomass burning in the model. The most significant difference in $f_{\mathrm{NF}}(0.4-0.5)$ is obtained for the mornings on 11 and 21 March, during which the BBOA plumes of $\sim 20 \mu \mathrm{g} \mathrm{m}^{-3}$ was not captured by the model.

\subsection{Spatial distribution of non-fossil OC in the Mexico City area}

Model results also provide valuable information on the relative importance of non-fossil and fossil sources at the regional scale. Figure 9 presents the average spatial distribution of the $f_{\mathrm{NF}}^{\mathrm{OC}}$ in the vicinity of Mexico City as predicted by ROB simulation during the second half of March 2006. Based on the biomass burning intensity two distinct periods have been selected, i.e. a high (17-22 March) and a low (2429 March) biomass burning period. For both periods, $f_{\mathrm{NF}}^{\mathrm{OC}}$ displays a strong spatial gradient between urban and remote areas. Lower $f_{\mathrm{NF}}^{\mathrm{OC}}$ contribution of $0.30-0.50$ is predicted over the Mexico City valley and its dominant outflow region to the north/northeast. These values are due to the importance of urban POA and SOA in this region, which has $f_{\mathrm{NF}}^{\mathrm{OC}}=0.20$ in the model. Higher $f_{\mathrm{NF}}^{\mathrm{OC}}(0.65-0.85)$ are predicted over the mountains surrounding the city, and over the western part of the plateau, which are less influenced by urban and industrial activities. Substantial differences in $f_{\mathrm{NF}}^{\mathrm{OC}}$ amplitude can also be seen between high and low biomass burning periods. During the low biomass burning period, $f_{\mathrm{NF}}^{\mathrm{OC}}$ ranges from $0.35-0.40$ in the valley, while this contribution increases up to $0.55-0.65$ over the mountains and exceeds 0.70 west of Mexico City. During high biomass burning periods, the contribution of non-fossil carbon is enhanced by about $0.10-0.20$ within the city and the surrounding hills. The fire plumes show a strong signature in $f_{\mathrm{NF}}^{\mathrm{OC}}$, an their effects can be seen over the mountains. 

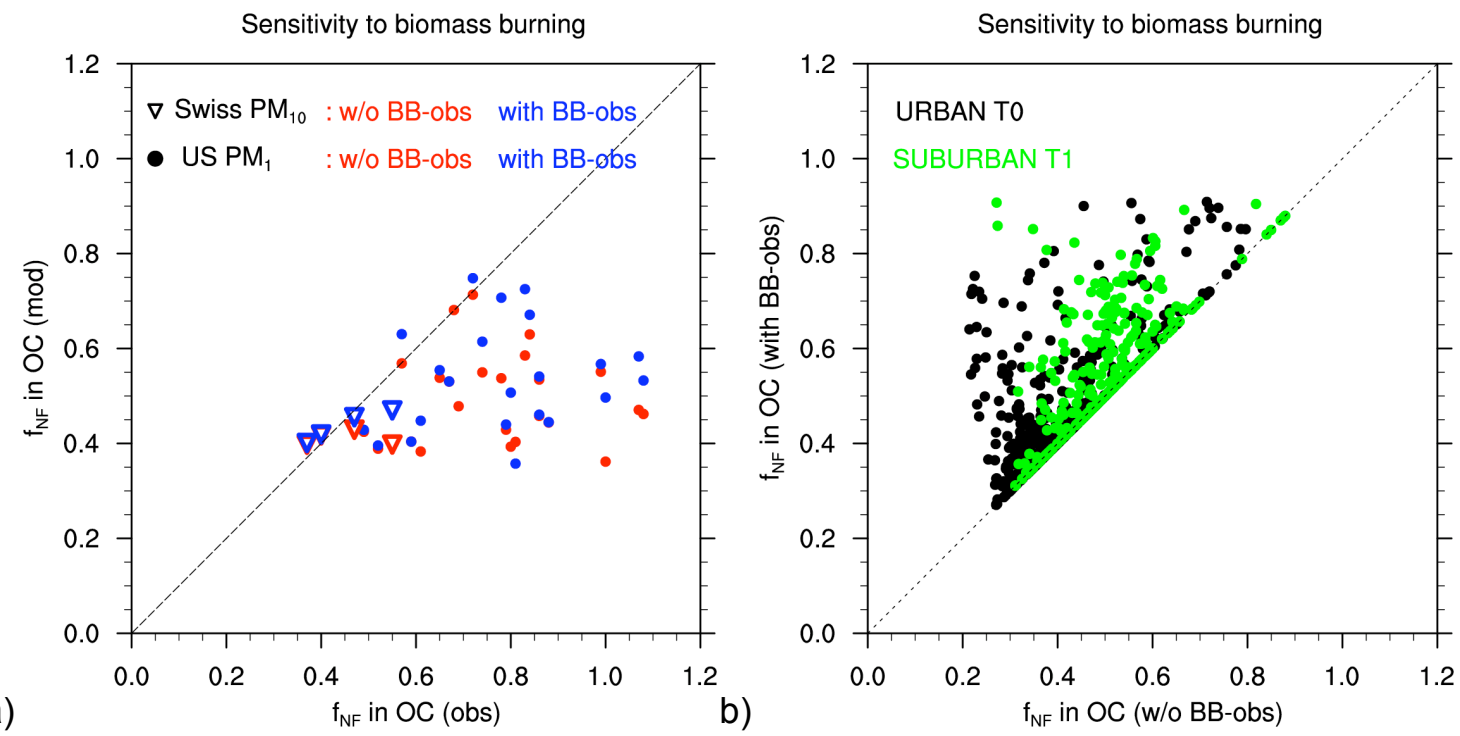

Fig. 8. (a) Comparison of predicted (ROB) and observed $f_{\mathrm{NF}}$ for US (dots) and Swiss (triangles) datasets at T0 and T1. Model sensitivity to biomass burning emissions is tested: $f_{\mathrm{NF}}$ was calculated using BBOA predicted by the model (red color), and using BBOA measured by the AMS (blue color). (b) Comparison of predicted (ROB) $f_{\mathrm{NF}}$ levels with and without correcting for the measured biomass burning contribution based on AMS observations.

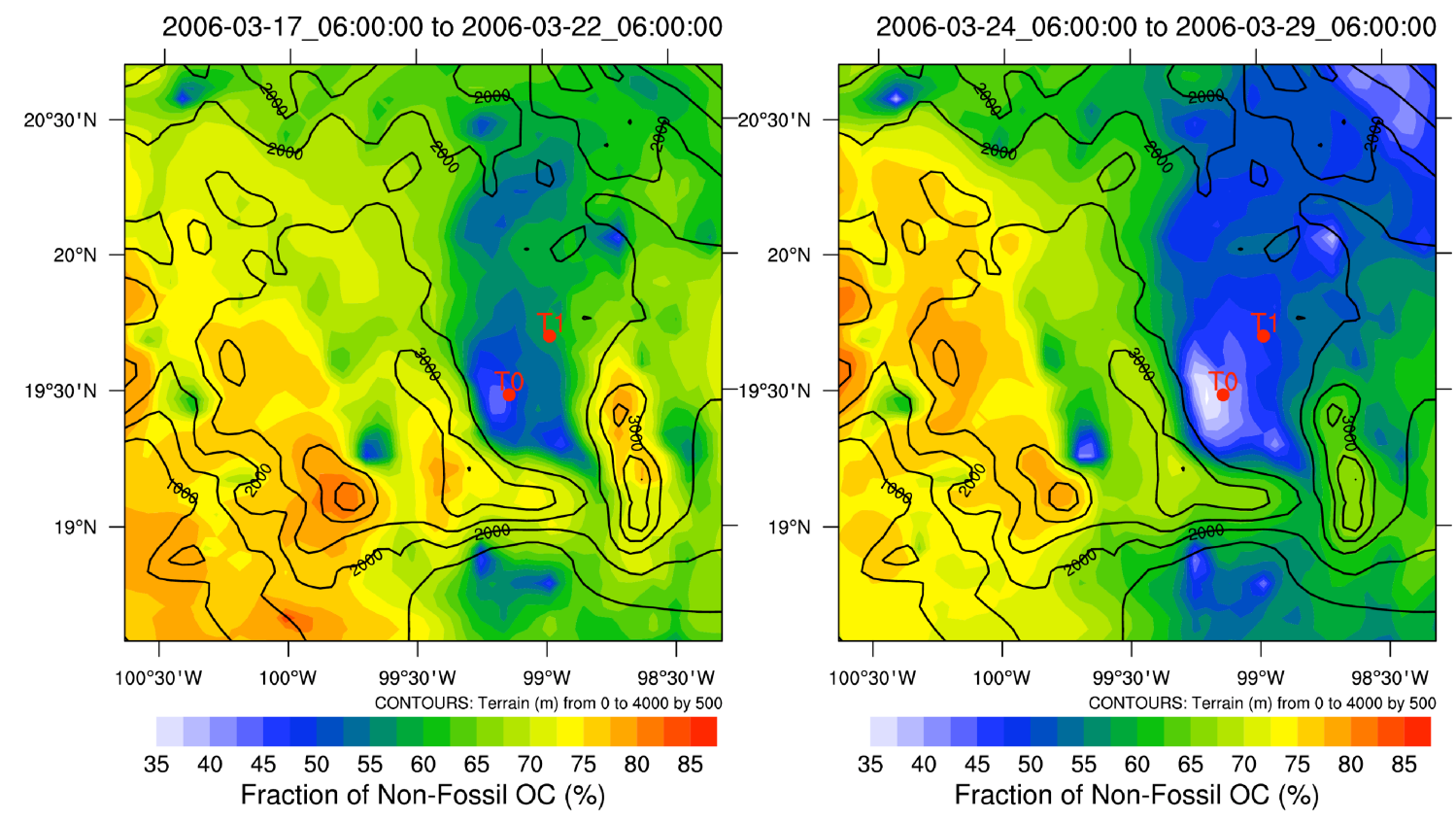

Fig. 9. Model predicted fraction of non-fossil carbon based on the ROB simulation. Fraction of non-fossil carbon was averaged over two distinct periods i.e. high biomass burning period (from 17-22 March 00:00 LT, left panel) and low biomass burning period (from 24-29 March 00:00 LT, right panel).

\subsection{Source apportionment of OA with ${ }^{14}$ C/AMS data}

The combined ${ }^{14} \mathrm{C}$ (Swiss filters) and AMS aerosol measurements allow for an estimation of the sources of OA (Szidat et al., 2004), beyond the evaluation of the total non-fossil and fossil fractions of OC (Lanz et al., 2008). We assume that fossil-/non-fossil fractions are the same for the Swiss filters and for AMS data. HOA is assumed to be 0.80 fossil and 0.20 non-fossil, in accordance with the assumptions above. The same assumption is applied to the SOA from urban precursors. 


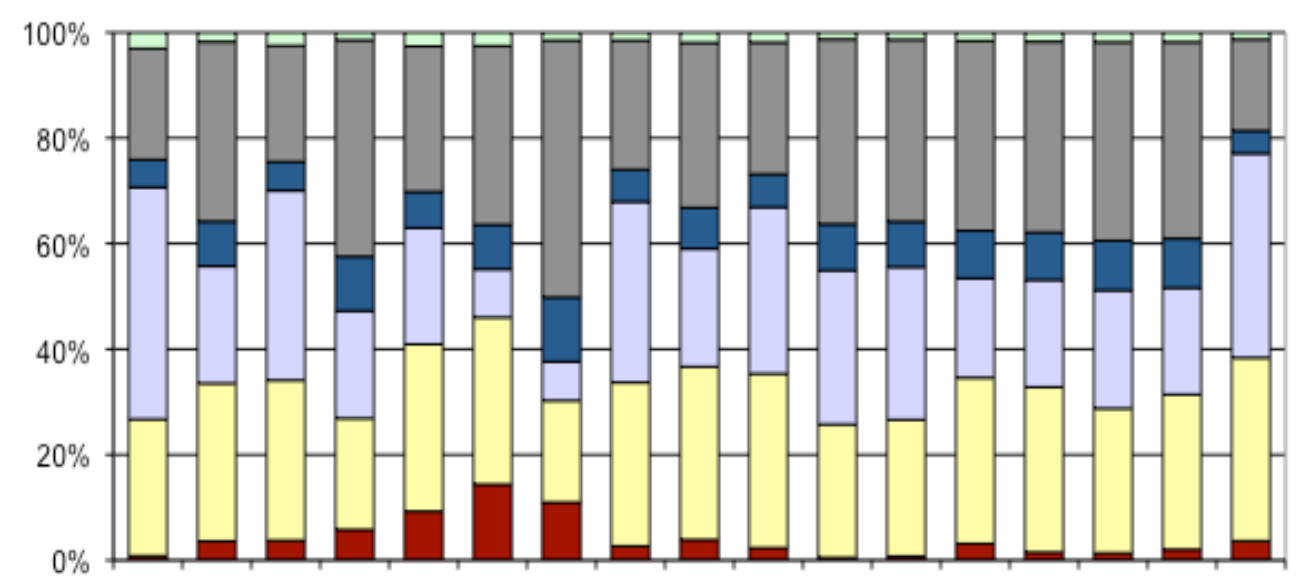

(a)
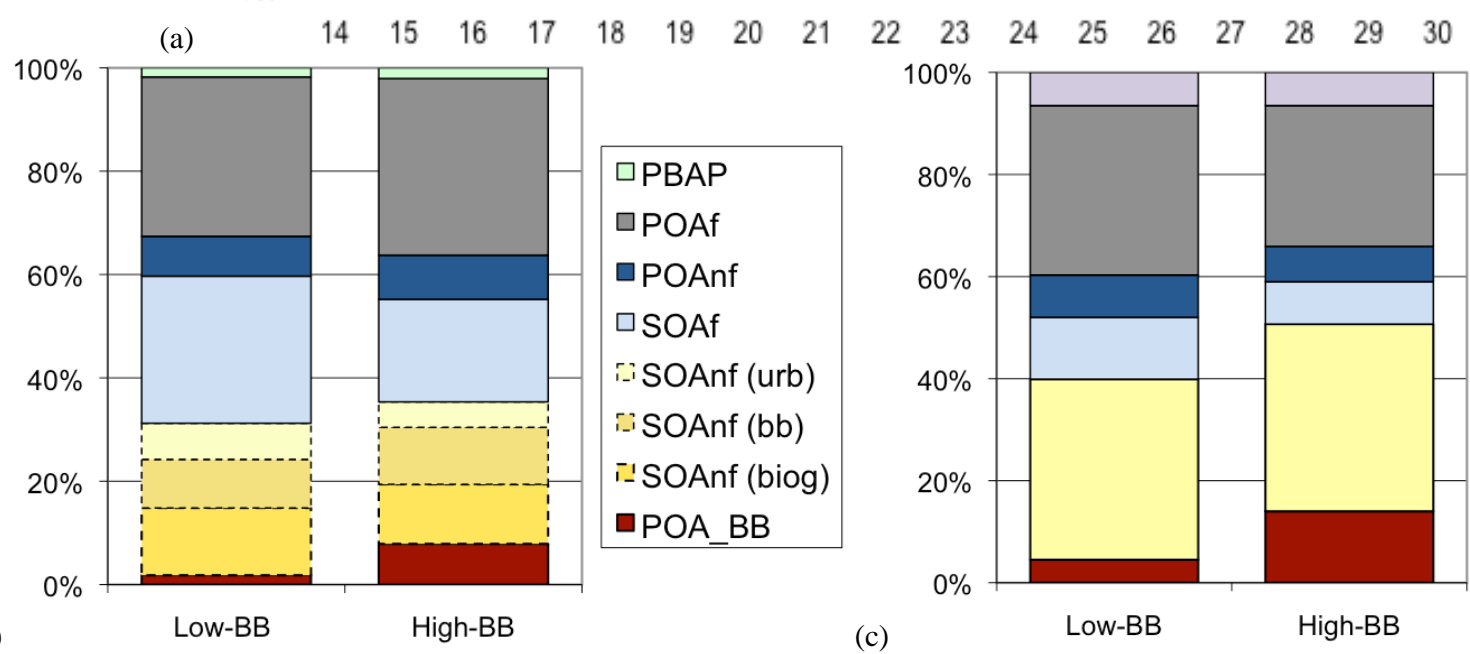

(c)

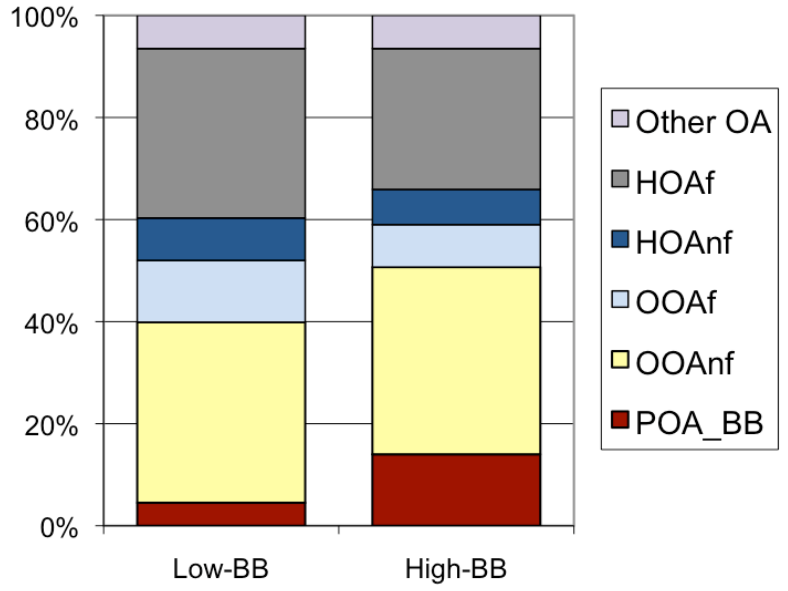

Fig. 10. Source specific contributions to organic $\mathrm{PM}_{10}$ aerosols at $\mathrm{T} 0$ as predicted by the ROB simulation during (a) the second half of March 2006, (b) the high and low biomass burning periods, and (c) as derived from four $\mathrm{PM}_{10}$ Swiss filters.

Figure 10a shows the model predictions for the daily average of the whole period, while Fig. 10b shows the model results over the Swiss filter periods, and Fig. 10c shows the results from the Swiss dataset. The AMS results indicate that biomass burning organic aerosol (BBOA) represents about 5 and $18 \%$ of OA during low and high biomass burning respectively. According to this method, the estimated fraction of non-fossil OOA $\left(\mathrm{OOA}_{\mathrm{NF}}\right)$ accounts for $\sim 35 \%$ of the OA and it is larger than the fossil fraction (8-12\%). Primary organic species (HOA) from fossil fuel burning represents about $30 \%$ while the contribution of the non-fossil HOA is less than $8 \%$. Other unidentified organic sources represent a minor fraction $(<8 \%)$.

Model predictions for the 14-30 March period show a somewhat different OA apportionment. The main difference is the larger proportion of fossil secondary organics i.e. $25-30 \%$, with a $15 \%$ higher model prediction, whereas the non-fossil fraction is about $5-10 \%$ lower in the model. The amount of primary organic aerosols from fossil and nonfossil sources is close to the observations. The non-fossil SOA fraction is composed of about $20 \%$ urban, $50 \%$ bio- genic and 30\% biomass burning sub-fractions in average, with some variability between low and high biomass burning periods (see Fig. 10b). The biomass burning SOA is mostly produced from the photochemistry of S/IVOC precursors emitted by fires that occurs in the vicinity of Mexico City (Hodzic et al., 2010). The model also predicts a factor of two lower proportion of primary biomass burning aerosols with the predicted fraction varying from 2 to $8 \%$, which is consistent with our earlier study (Hodzic et al., 2010).

\section{Conclusions}

The CHIMERE model has been applied to the Mexico City metropolitan area during March 2006 and compared with aerosol ${ }^{14} \mathrm{C}$ and AMS measurements to investigate the origin of elevated levels of non-fossil (NF) carbon aerosols observed in this urban area. The followings findings emerged from the study: 
i. The model results suggest that the relatively high fraction of non-fossil carbon found in Mexico City seems to arise from the combination of biogenic SOA sources, biomass burning POA and SOA, as well as non-fossil urban POA and SOA. The study shows, in agreement with previous assessments, that the difference between the two ${ }^{14} \mathrm{C}$ datasets could not be explained by the different size cuts between the two sets of filters, implying large uncertainties in field measurements of ${ }^{14} \mathrm{C}$. Much smaller difference $(<2 \%)$ between $\mathrm{PM}_{1}$ and $\mathrm{PM}_{10} f_{\mathrm{NF}}^{\mathrm{OC}}$ values is suggested from model results. The contribution of primary biological particles (PBAP) is relatively small both in terms of surface concentrations $\left(\sim 0.2 \mu \mathrm{g} \mathrm{m}^{-3}\right)$ and non-fossil carbon. A $10-20 \%$ increase in $f_{\mathrm{NF}}^{\mathrm{OC}}$ was observed for both sets of filters as well as modeled values during enhanced wildfire activity in comparison to periods when fires were suppressed by rain, quantifying the contribution of that source to the measured OC levels.

ii. Modeling results using the most complete SOA model (ROB simulation) show reasonable agreement with the $\mathrm{PM}_{10}$ Swiss dataset but are lower than the $\mathrm{PM}_{1}$ US dataset. None of the simulations could explain the elevated values of $f_{\mathrm{NF}}$ reported by the US dataset, especially at the suburban site. If the Swiss dataset was the most accurate that would imply that our modeling of the organic aerosol mixture is reasonable especially during low biomass-burning periods. Conversely, if the US dataset was more accurate, that would indicate that the model predictions are too low for reasons that we have not been able to explain in this work. To make further progress it is urgent to understand and resolve the measurement discrepancy.

iii. Similar $f_{\mathrm{NF}}^{\mathrm{TC}}$ predictions are found for the GRI run, with values generally $0.05-0.10$ lower than for ROB simulations. The fraction of non-fossil carbon in urban emissions has a large impact on the simulations, and this parameter needs to be further constrained by additional source and ambient measurements. Correcting for modeling errors for the biomass burning aerosols increased the modeled ${ }^{14} \mathrm{C}$ by $\sim 5-10 \%$ during the sampling periods and reduces the differences with the measurements, but could not explain the discrepancies with the US dataset. The model results also indicate a strong spatial pattern on $f_{\mathrm{NF}}^{\mathrm{OC}}$, with lower values in the urban area and larger values in regional air, which is also observed in the measurements.

iv. The combined analysis of radiocarbon and AMS data allowed assessing the model skill (ROB simulation) in reproducing the source-specific OA composition. It was found that the contribution of fossil sources to secondary organic aerosols was overpredicted by $10-20 \%$, while that of non-fossil sources was reproduced within
5-10\%. The comparison also confirms that the biomass burning contribution to POA is a factor of 2 lower than observed as already seen by Hodzic et al. (2010).

Our results highlight the benefits of a complementary use of aerosol ${ }^{14} \mathrm{C}$ measurements and AMS data for air quality modeling studies, as well as the critical need for higher temporal resolution of ${ }^{14} \mathrm{C}$ measurements i.e. $\leq 3 \mathrm{~h}$ instead of $12 \mathrm{~h}$ or $24 \mathrm{~h}$ filters and ${ }^{14} \mathrm{C}$ measurement intercomparisons, in order to better quantify the ${ }^{14} \mathrm{C}$ measurement noise, diurnal cycle, possible effects of plumes and "hot" sources, etc. in future studies.

\section{Supplementary material related to this article is available online at: http://www.atmos-chem-phys.net/10/10997/2010/ acp-10-10997-2010-supplement.pdf.}

Acknowledgements. The National Center for Atmospheric Research is operated by the University Corporation for Atmospheric Research on behalf of the National Science Foundation. We are also grateful for support from grants NSF ATM-0449815, NOAA NA08OAR4310565, and DOE DEFG0208ER6462. We gratefully acknowledge J. Gaffney (University of Arkansas) and N. Marley (University of Arkansas) for sharing their ${ }^{14} \mathrm{C}$ dataset, which was obtained as part of the DOE Atmospheric Systems Research program effort. Jerome Fast was supported by the ASR program under contract DE-AC06-76RLO 1830 at Pacific Northwest National Laboratory. We are grateful to Thomas Karl (NCAR) for numerous discussions on the topic.

Edited by: T. Röckmann

\section{References}

Aiken, A. C., DeCarlo, P. F., Kroll, J. H., Worsnop, D. R., Huffman, J. A., Docherty, K. S., Ulbrich, I. M., Mohr, C., Kimmel, J. R., Sueper, D., Sun, Y., Zhang, Q., Trimborn, A., Northway, M., Ziemann, P. J., Canagaratna, M. R., Onasch, T. B., Alfarra, M. R., Prévôt, A. S. H., Dommen, J., Duplissy, J., Metzger, A., Baltensperger, U., and Jimenez, J. L.: O/C and OM/OC Ratios of primary, secondary, and ambient organic aerosols with high resolution time-of-flight aerosol mass spectrometry, Environ. Sci. Technol., 42, 4478-4485, doi:10.1021/es703009q, 2008.

Aiken, A. C., Salcedo, D., Cubison, M. J., Huffman, J. A., DeCarlo, P. F., Ulbrich, I. M., Docherty, K. S., Sueper, D., Kimmel, J. R., Worsnop, D. R., Trimborn, A., Northway, M., Stone, E. A., Schauer, J. J., Volkamer, R. M., Fortner, E., de Foy, B., Wang, J., Laskin, A., Shutthanandan, V., Zheng, J., Zhang, R., Gaffney, J., Marley, N. A., Paredes-Miranda, G., Arnott, W. P., Molina, L. T., Sosa, G., and Jimenez, J. L.: Mexico City aerosol analysis during MILAGRO using high resolution aerosol mass spectrometry at the urban supersite (T0) - Part 1: Fine particle composition and organic source apportionment, Atmos. Chem. Phys., 9, 66336653, doi:10.5194/acp-9-6633-2009, 2009.

Aiken, A. C., de Foy, B., Wiedinmyer, C., DeCarlo, P. F., Ulbrich, I. M., Wehrli, M. N., Szidat, S., Prevot, A. S. H., Noda, 
J., Wacker, L., Volkamer, R., Fortner, E., Wang, J., Laskin, A., Shutthanandan, V., Zheng, J., Zhang, R., Paredes-Miranda, G., Arnott, W. P., Molina, L. T., Sosa, G., Querol, X., and Jimenez, J. L.: Mexico city aerosol analysis during MILAGRO using high resolution aerosol mass spectrometry at the urban supersite (T0) - Part 2: Analysis of the biomass burning contribution and the non-fossil carbon fraction, Atmos. Chem. Phys., 10, 5315-5341, doi:10.5194/acp-10-5315-2010, 2010.

Bench, G., Fallon, S., Schichtel, B., Malm, W., and McDade, C.: Relative contributions of fossil and contemporary carbon sources to $\mathrm{PM}_{2.5}$ aerosols at nine Interagency Monitoring for Protection of Visual Environments (IMPROVE) network sites, J. Geophys. Res., 112, D10205, doi:10.1029/2006JD0077082007, 2007.

CAM (Comision Ambiental Metropolitana): Inventario de Emisiones 2002 de la Zona Metropolitana del Valle de Mexico, Mexico, 2004.

Carlton, A. G., Pinder, R. W., and Bhave, P. V.: To What Extent Can Biogenic SOA be Controlled?, Environ. Sci. Technol, 44, 3376-3380, 2010.

Christian, T. J., Yokelson, R. J., Cárdenas, B., Molina, L. T., Engling, G., and Hsu, S.-C.: Trace gas and particle emissions from domestic and industrial biofuel use and garbage burning in central Mexico, Atmos. Chem. Phys., 10, 565-584, doi:10.5194/acp-10-565-2010, 2010.

Currie, L. A., Sheffield, A. E., Riederer, G. E., and Gordon, G. E.: Improved atmospheric understanding through exploratory data analysis and complementary modeling: the urban $\mathrm{K}-\mathrm{Pb}-\mathrm{C}$ system, Atmos. Environ., 28, 1359-1369, 1994.

de Gouw, J. and Jimenez, J. L.: Organic Aerosols in the Earth's Atmosphere, Environ. Sci. Technol., 43, 7614-7618, 2009.

de Gouw, J. A., Middlebrook, A. M., Warneke, C., Goldan, P. D., Kuster, W. C., Roberts, J. M., Fehsenfeld, F. C., Worsnop, D. R., Canagaratna, M. R., Pszenny, A. A. P., Keene, W. C., Marchewka, M., Bertman, S. B., and Bates, T. S.: Budget of organic carbon in a polluted atmosphere: Results from the New England Air Quality Study in 2002, J. Geophys. Res., 110, D16305, doi:10.1029/2004JD005623, 2005.

de Gouw, J. A., Welsh-Bon, D., Warneke, C., Kuster, W. C., Alexander, L., Baker, A. K., Beyersdorf, A. J., Blake, D. R., Canagaratna, M., Celada, A. T., Huey, L. G., Junkermann, W., Onasch, T. B., Salcido, A., Sjostedt, S. J., Sullivan, A. P., Tanner, D. J., Vargas, O., Weber, R. J., Worsnop, D. R., Yu, X. Y., and Zaveri, R.: Emission and chemistry of organic carbon in the gas and aerosol phase at a sub-urban site near Mexico City in March 2006 during the MILAGRO study, Atmos. Chem. Phys., 9, 3425-3442, doi:10.5194/acp-9-3425-2009, 2009.

Fast, J., Aiken, A. C., Allan, J., Alexander, L., Campos, T., Canagaratna, M. R., Chapman, E., DeCarlo, P. F., de Foy, B., Gaffney, J., de Gouw, J., Doran, J. C., Emmons, L., Hodzic, A., Herndon, S. C., Huey, G., Jayne, J. T., Jimenez, J. L., Kleinman, L., Kuster, W., Marley, N., Russell, L., Ochoa, C., Onasch, T. B., Pekour, M., Song, C., Ulbrich, I. M., Warneke, C., WelshBon, D., Wiedinmyer, C., Worsnop, D. R., Yu, X.-Y., and Zaveri, R.: Evaluating simulated primary anthropogenic and biomass burning organic aerosols during MILAGRO: implications for assessing treatments of secondary organic aerosols, Atmos. Chem. Phys., 9, 6191-6215, doi:10.5194/acp-9-6191-2009, 2009.

Gelencser, A., May, B., Simpson, D., Sanchez-Ochoa, A., Kasper-Giebl, A., Puxbaum, H., Caseiro, A., Pio, C., and Legrand, M.: Source apportionment of $\mathrm{PM}_{2.5}$ organic aerosol over Europe: Primary/secondary, natural/anthropogenic, and fossil/biogenic origin, J. Geophys. Res., 112, D23S04, doi:10.1029/2006JD008094, 2007.

Grieshop, A. P., Logue, J. M., Donahue, N. M., and Robinson, A. L.: Laboratory investigation of photochemical oxidation of organic aerosol from wood fires 1: measurement and simulation of organic aerosol evolution, Atmos. Chem. Phys., 9, 1263-1277, doi:10.5194/acp-9-1263-2009, 2009.

Guenther, A., Karl, T., Harley, P., Wiedinmyer, C., Palmer, P. I., and Geron, C.: Estimates of global terrestrial isoprene emissions using MEGAN (Model of Emissions of Gases and Aerosols from Nature), Atmos. Chem. Phys., 6, 3181-3210, doi:10.5194/acp-63181-2006, 2006.

Hallquist, M., Wenger, J. C., Baltensperger, U., Rudich, Y., Simpson, D., Claeys, M., Dommen, J., Donahue, N. M., George, C., Goldstein, A. H., Hamilton, J. F., Herrmann, H., Hoffmann, T., Iinuma, Y., Jang, M., Jenkin, M. E., Jimenez, J. L., Kiendler-Scharr, A., Maenhaut, W., McFiggans, G., Mentel, Th. F., Monod, A., Prévôt, A. S. H., Seinfeld, J. H., Surratt, J. D., Szmigielski, R., and Wildt, J.: The formation, properties and impact of secondary organic aerosol: current and emerging issues, Atmos. Chem. Phys., 9, 5155-5236, doi:10.5194/acp-95155-2009, 2009.

Heald, C. L. and Spracklen, D. V.: Atmospheric budget of primary biological aerosol particles from fungal spores, Geophys. Res. Lett., 36, L09806, doi:10.1029/2009GL037493, 2009.

Hildemann, L. M., Klinedinst, D. B., Klouda, G. A., Currie, L. A., and Cass, G. R.: Sources of urban contemporary carbon aerosol, Environ. Sci. Technol., 28, 1565-1576, 1994.

Hodzic, A., Jimenez, J. L., Madronich, S., Aiken, A. C., Bessagnet, B., Curci, G., Fast, J., Lamarque, J.-F., Onasch, T. B., Roux, G., Schauer, J. J., Stone, E. A., and Ulbrich, I. M.: Modeling organic aerosols during MILAGRO: importance of biogenic secondary organic aerosols, Atmos. Chem. Phys., 9, 6949-6981, doi:10.5194/acp-9-6949-2009, 2009.

Hodzic, A., Jimenez, J. L., Madronich, S., Canagaratna, M. R., DeCarlo, P. F., Kleinman, L., and Fast, J.: Modeling organic aerosols in a megacity: potential contribution of semi-volatile and intermediate volatility primary organic compounds to secondary organic aerosol formation, Atmos. Chem. Phys., 10, 5491-5514, doi:10.5194/acp-10-5491-2010, 2010.

Huffman, J. A., Docherty, K. S., Aiken, A. C., Cubison, M. J., Ulbrich, I. M., DeCarlo, P. F., Sueper, D., Jayne, J. T., Worsnop, D. R., Ziemann, P. J., and Jimenez, J. L.: Chemically-resolved aerosol volatility measurements from two megacity field studies, Atmos. Chem. Phys., 9, 7161-7182, doi:10.5194/acp-9-71612009, 2009.

Jimenez, J. L., Canagaratna, M. R., Donahue, N. M., Prévôt, A. S. H., Zhang, Q., Kroll, J. H., DeCarlo, P. F., Allan, J. D., Coe, H., Ng, N. L., Aiken, A. C., Docherty, K. S., Ulbrich, I. M., Grieshop, A. P., Robinson, A. L., Duplissy, J., Smith, J. D., Wilson, K. R., Lanz, V. A., Hueglin, C., Sun, Y. L., Tian, J., Laaksonen, A., Raatikainen, T., Rautiainen, J., Vaattovaara, P., Ehn, M., Kulmala, M., Tomlinson, J. M., Collins, D. R., Cubison, M. J., Dunlea, E. J., Huffman, J. A., Onasch, T. B., Alfarra, M. R., Williams, P. I., Bower, K., Kondo, Y., Schneider, J., Drewnick, F., Borrmann, S., Weimer, S., Demerjian, K., Salcedo, D., Cottrell, L., Griffin, R., Takami, A., Miyoshi, T., Hatakeyama, S., 
Shimono, A., Sun, J. Y., Zhang, Y. M., Dzepina, K., Kimmel, J. R., Sueper, D., Jayne, J. T., Herndon, S. C., Trimborn, A. M., Williams, L. R., Wood, E. C., Middlebrook, A. M., Kolb, C. E., Baltensperger, U., and Worsnop, D. R.: Evolution of Organic Aerosols in the Atmosphere, Science, 326(5959), 1525-1529, 2009.

Ke, L., Ding, X., Tanner, R. L., Schauer, J. J., and Zheng, M.: Source contributions to carbonaceous aerosols in the Tennessee Valley Region, Atmos. Environ., 41, 8898-8923, 2007.

Klinedinst, D. B. and Currie, L. A.: Direct quantification of $\mathrm{PM}_{2.5}$ fossil and biomass carbon within the Northern Front Range air quality study's domain, Environ. Sci. Technol., 33, 4146-4154, 1999.

Lanz, V. A., Alfarra, M. R., Baltensperger, U., Buchmann, B., Hueglin, C., Szidat, S., Wehrli, M. N., Wacker, L., Weimer, S., Caseiro, A., Puxbaum, A., and Prévôt, A. S. H.: Source attribution of submicron organic aerosols during wintertime inversions by advanced factor analysis of aerosol mass spectra, Environ. Sci. Technol., 42, 214-220, doi:10.1021/es0707207, 2008.

Legrand, M. and Puxbaum, H.: Summary of the CARBOSOL project: Present and retrospective state of organic versus inorganic aerosol over Europe, J. Geophys. Res., 112, D23S01, doi:10.1029/2006JD008271, 2007.

Lemire, K. R., Allen, D. T., Klouda, G. A., and Lewis, C. W.: Fine particulate matter source attribution for Southeast Texas using ${ }^{14} \mathrm{C} /{ }^{13} \mathrm{C}$ ratios, J. Geophys. Res., 107(D22), 4613, doi:10.1029/2002JD002339, 2002.

Levin, I., Naegler, T., Kromer, B., Diehl, M., Francey, R. J., GomezPelaez, A. J., Steele, L. P., Wagenbach, D., Weller, R., and Worthy, D. E.: Observations and modelling of the global distribution and long-term trend of atmospheric ${ }^{14} \mathrm{CO}_{2}$, Tellus B, 62, 26-46, 2010.

Lewis, C. W. and Stiles, D. C.: Radiocarbon content of $\mathrm{PM}_{2.5}$ ambient aerosol in Tampa, FL, Aerosol Sci. Technol., 40, 189-196, 2006.

Lewis, C. W., Klouda, G. A., and Ellenson, W. D.: Radiocarbon measurement of the biogenic contribution to summertime $\mathrm{PM}_{2.5}$ ambient aerosol in Nashville, TN, Atmos. Environ., 38, 60536061, 2004.

Mahowald, N., Jickells, T. D., Baker, A. R., Artaxo, P., BenitezNelson, C. R., Bergametti, G., Bond, T. C., Chen, Y., Cohen, D. D., Herut, B., Kubilay, N., Losno, R., Luo, C., Maenhaut, W., McGee, K. A., Okin, G. S., Siefert, R. L., and Tsukuda, S.: Global distribution of atmospheric phosphorus sources, concentrations and deposition rates, and anthropogenic impacts, Global Biogeochem. Cy., 22, GB4026, doi:10.1029/2008GB003240, 2008.

Marley, N. A., Gaffney, J. S., Tackett, M., Sturchio, N. C., Heraty, L., Martinez, N., Hardy, K. D., Marchany-Rivera, A., Guilderson, T., MacMillan, A., and Steelman, K.: The impact of biogenic carbon sources on aerosol absorption in Mexico City, Atmos. Chem. Phys., 9, 1537-1549, doi:10.5194/acp-9-1537-2009, 2009.

Murphy, D. M., Cziczo, D. J., Froyd, K. D., Hudson, P. K., Matthew, B. M., Middlebrook, A. M., Peltier, R. E., Sullivan, A., Thomson, D. S., and Weber, R. J.: Single-particle mass spectrometry of tropospheric aerosol particles, J. Geophys. Res., 111, D23S32, doi:10.1029/2006JD007340, 2006.

Molina, L. T., Madronich, S., Gaffney, J. S., Apel, E., de Foy, B.,
Fast, J., Ferrare, R., Herndon, S., Jimenez, J. L., Lamb, B., Osornio-Vargas, A. R., Russell, P., Schauer, J. J., Stevens, P. S., Volkamer, R., and Zavala, M.: An overview of the MILAGRO 2006 Campaign: Mexico City emissions and their transport and transformation, Atmos. Chem. Phys., 10, 8697-8760, doi:10.5194/acp-10-8697-2010, 2010.

Ng, N. L., Canagaratna, M. R., Zhang, Q., Jimenez, J. L., Tian, J., Ulbrich, I. M., Kroll, J. H., Docherty, K. S., Chhabra, P. S., Bahreini, R., Murphy, S. M., Seinfeld, J. H., Hildebrandt, L., Donahue, N. M., DeCarlo, P. F., Lanz, V. A., Prévôt, A. S. H., Dinar, E., Rudich, Y., and Worsnop, D. R.: Organic aerosol components observed in Northern Hemispheric datasets from Aerosol Mass Spectrometry, Atmos. Chem. Phys., 10, 46254641, doi:10.5194/acp-10-4625-2010, 2010.

Paredes-Miranda, G., Arnott, W. P., Jimenez, J. L., Aiken, A. C., Gaffney, J. S., and Marley, N. A.: Primary and secondary contributions to aerosol light scattering and absorption in Mexico City during the MILAGRO 2006 campaign, Atmos. Chem. Phys., 9, 3721-3730, doi:10.5194/acp-9-3721-2009, 2009.

Sandradewi, J., Prévôt, A. S. H., Alfarra, M. R., Szidat, S., Wehrli, M. N., Ruff, M., Weimer, S., Lanz, V. A., Weingartner, E., Perron, N., Caseiro, A., Kasper-Giebl, A., Puxbaum, H., Wacker, L., and Baltensperger, U.: Comparison of several wood smoke markers and source apportionment methods for wood burning particulate mass, Atmos. Chem. Phys. Discuss., 8, 8091-8118, doi:10.5194/acpd-8-8091-2008, 2008.

Pun, B.: Modeling secondary organic aerosol formation via multiphase partitioning with molecular data, Environ. Sci. Technol., 40, 4722-4731, 2006.

Robinson, A. L., Donahue, N. M., Shrivastava, M. K., Weitkamp, E. A., Sage, A. M., Grieshop, A. P., Lane, T. E., Pandis, S. N., and Pierce, J. R.: Rethinking organic aerosols: Semivolatile emissions and photochemical aging, Science, 315, 1259-1262, 2007.

Schichtel, B. A., Malm, W. C., Bench, G., Fallon, S., McDade, C. E., Chow, J. C., and Watson, J. G.: Fossil and contemporary fine particulate carbon fractions at 12 rural and urban sites in the United States, J. Geophys. Res., 113, D02311, doi:10.1029/2007JD008605, 2008.

Shilling, J. E., Chen, Q., King, S. M., Rosenoern, T., Kroll, J. H., Worsnop, D. R., DeCarlo, P. F., Aiken, A. C., Sueper, D., Jimenez, J. L., and Martin, S. T.: Loading-dependent elemental composition of $\alpha$-pinene SOA particles, Atmos. Chem. Phys., 9, 771-782, doi:10.5194/acp-9-771-2009, 2009.

Stone, E. A., Snyder, D. C., Sheesley, R. J., Sullivan, A. P., Weber, R. J., and Schauer, J. J.: Source apportionment of fine organic aerosol in Mexico City during the MILAGRO experiment 2006, Atmos. Chem. Phys., 8, 1249-1259, doi:10.5194/acp-81249-2008, 2008.

Stuiver, M. and Polach, H. A.: Discussion: Reporting of ${ }^{14} \mathrm{C}$ data, Radiocarbon, 19, 355-365, 1977.

Szidat, S.: Radiocarbon analysis of carbonaceous aerosols: recent developments, Chimia, 63, 157-161, doi:10.2533/chimia.2009.157, 2009a.

Szidat, S., Jenk, T. M., Gäggeler, H. W., Synal, H.-A., Fisseha, R., Baltensperger, U., Kalberer, M., Samburova, V., Wacker, L., Saurer, M., Schwikowski, M., and Hajdas, I.: Source apportionment of aerosols by ${ }^{14} \mathrm{C}$ measurements in different carbonaceous particle fractions, Radiocarbon, 46, 475-484, 2004.

Szidat, S., Jenk, T. M., Synal, H.-A., Kalberer, M., Wacker, L., Ha- 
jdas, I., Kasper-Giebl, A., and Baltensperger, U.: Contributions of fossil fuel, biomass-burning, and biogenic emissions to carbonaceous aerosols in Zurich as traced by ${ }^{14} \mathrm{C}$, J. Geophys. Res., 111, D07206, doi:10.1029/2005JD006590, 2006.

Szidat, S., Prévôt, A. S. H., Sandradewi, J., Alfarra, M. R., Synal, H.-A., Wacker, L., and Baltensperger, U.: Dominant impact of residential wood burning on particulate matter in Alpine valleys during winter, Geophys. Res. Lett., 34, L05820, doi:10.1029/2006GL028325, 2007.

Szidat, S., Ruff, M., Perron, N., Wacker, L., Synal, H.-A., Hallquist, M., Shannigrahi, A. S., Yttri, K. E., Dye, C., and Simpson, D.: Fossil and non-fossil sources of organic carbon (OC) and elemental carbon (EC) in Göteborg, Sweden, Atmos. Chem. Phys., 9, 1521-1535, doi:10.5194/acp-9-1521-2009, 2009b.

Takahashi, K., Hirabayashi, M., Tanabe, K., Shibata, Y., Nishikawa, M., and Sakamoto, K.: Radiocarbon content in urban atmospheric aerosols, Water Air Soil Poll., 185, 305-310, 2007.

Tanner, R. L., Parkhurst, W. J., and McNichol, A. P.: Fossil sources of ambient aerosol carbon based on ${ }^{14} \mathrm{C}$ measurements, Aerosol Sci. Technol., 38(S1), 133-139, 2004.

Turpin, B. J. and Lim, H. J.: Species contributions to $\mathrm{PM}_{2.5}$ mass concentrations: Revisiting common assumptions for estimating organic mass, Aerosol Sci. Technol., 35(1), 602-610, 2001.

Ulbrich, I. M., Canagaratna, M. R., Zhang, Q., Worsnop, D. R., and Jimenez, J. L.: Interpretation of organic components from Positive Matrix Factorization of aerosol mass spectrometric data, Atmos. Chem. Phys., 9, 2891-2918, doi:10.5194/acp-9-2891-2009, 2009.

Ward, T. J., Rinehart, L. R., and Lange, T.: The 2003/2004 Libby, Montana $\mathrm{PM}_{2.5}$ source apportionment research study, Aerosol Sci. Technol., 40, 166-177, 2006.
Weber, R. J., Sullivan, A. P., Peltier, R. E., Russell, A., Yan, B., Zheng, M., de Gouw, J., Warneke, C., Brock, C., Holloway, J. S., Atlas, E. L., and Edgerton, E.: A study of secondary organic aerosol formation in the anthropogenic-influenced southeastern United States, J. Geophys. Res., 112(D13), D13302, doi:10.1029/2007JD008408, 2007.

Wiedinmyer, C., Quayle, B., Geron, C., Belote, A., McKenzie, D., Zhang, X. Y., O'Neill, S., and Wynne, K. K.: Estimating emissions from fires in North America for air quality modeling, Atmos. Environ., 40, 3419-3432, 2006.

Yamamoto, N., Muramoto, A., Yoshinaga, J., Shibata, K., Endo, M., Endo, O., Hirabayashi, M., Tanabe, K., Goto, S., Yoneda, M., and Shibata, Y.: Comparison of carbonaceous aerosols in Tokyo before and after implementation of diesel exhaust restrictions, Environ. Sci. Technol., 41, 6357-6362, 2007.

Yang, F., He, K., Ye, B., Chen, X., Cha, L., Cadle, S. H., Chan, T., and Mulawa, P. A.: One-year record of organic and elemental carbon in fine particles in downtown Beijing and Shanghai, Atmos. Chem. Phys., 5, 1449-1457, doi:10.5194/acp-5-1449-2005, 2005.

Zencak, Z., Elmquist, M., and Gustafsson, Ö.: Quantification and radiocarbon source apportionment of black carbon in atmospheric aerosols using the CTO-375 method, Atmos. Environ., 41, 7895-7906, 2007.

Zheng, M., Ke, L., Edgerton, E. S., Schauer, J. J., Dong, M., and Russell, A. G.: Spatial distribution of carbonaceous aerosol in the southeastern United States using molecular markers and carbon isotope data, J. Geophys. Res., 111, D10S06, doi:10.1029/2005JD006777, 2006. 